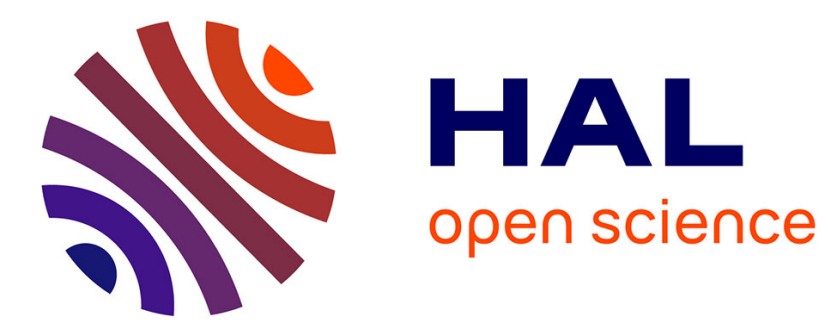

\title{
Geomorphological system and landscape coevolution in Mercurey (Burgundy, France): hypothesis of an early soil maintenance strategy
}

Brian Chaize, Etienne Cossart, Aurélien Christol, Matthieu Fressard

\section{- To cite this version:}

Brian Chaize, Etienne Cossart, Aurélien Christol, Matthieu Fressard. Geomorphological system and landscape coevolution in Mercurey (Burgundy, France): hypothesis of an early soil maintenance strategy. Géomorphologie : relief, processus, environnement, 2020. hal-03118232

\section{HAL Id: hal-03118232 \\ https://hal.science/hal-03118232}

Submitted on 26 Nov 2021

HAL is a multi-disciplinary open access archive for the deposit and dissemination of scientific research documents, whether they are published or not. The documents may come from teaching and research institutions in France or abroad, or from public or private research centers.
L'archive ouverte pluridisciplinaire HAL, est destinée au dépôt et à la diffusion de documents scientifiques de niveau recherche, publiés ou non, émanant des établissements d'enseignement et de recherche français ou étrangers, des laboratoires publics ou privés. 


\section{Géomorphologie : relief, processus,}

environnement

vol. $27-n^{\circ} 2$ | 2021

Actes des 21 èmes Journées des Jeunes

Géomorphologues

\section{Geomorphological system and landscape coevolution in Mercurey (Burgundy, France): hypothesis of an early soil maintenance strategy}

Coévolution du système géomorphologique et du paysage de Mercurey

(Bourgogne, France) : hypothèse d'une stratégie précoce de gestion de la ressource en sol

Brian Chaize, Étienne Cossart, Aurélien Christol et Mathieu Fressard

\section{OpenEdition}

Journals

Édition électronique

URL : https://journals.openedition.org/geomorphologie/14882

DOI : 10.4000/geomorphologie.14882

ISSN : 1957-777X

\section{Éditeur}

Groupe français de géomorphologie

Édition imprimée

Date de publication : 30 juin 2021

Pagination : 107-126

ISBN : 978-2-913282-91-9

ISSN : 1266-5304

Ce document vous est offert par BU de l'Université Jean Moulin Lyon 3

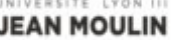

Référence électronique

Brian Chaize, Étienne Cossart, Aurélien Christol et Mathieu Fressard, « Geomorphological system and landscape coevolution in Mercurey (Burgundy, France): hypothesis of an early soil maintenance strategy ", Géomorphologie : relief, processus, environnement [En ligne], vol. 27 - n 2 | 2021, mis en ligne le 15 décembre 2020, consulté le 26 novembre 2021. URL : http://journals.openedition.org/ geomorphologie/14882 ; DOI : https://doi.org/10.4000/geomorphologie.14882 


\title{
Geomorphological system and landscape coevolution in Mercurey (Burgundy, France): hypothesis of an early soil maintenance strategy
}

\section{Coévolution du système géomorphologique et du paysage de Mercurey (Bourgogne, France): hypothèse d'une stratégie précoce de gestion de la ressource en sol}

\author{
Brian Chaize ${ }^{\mathrm{a}^{*}}$, Étienne Cossart ${ }^{\mathrm{a}}$, Aurélien Christol $^{\mathrm{a}}$, Mathieu Fressard ${ }^{\mathrm{b}}$ \\ ${ }^{a}$ Université de Lyon 3 Jean Moulin, UMR 5600 CNRS - Environnement Ville Société (EVS), 18, rue Chevreul, 69007 Lyon, France \\ ${ }^{\mathrm{b}}$ CNRS, UMR 5600 - Environnement Ville Société (EVS), Université de Lyon 2, 18, rue Chevreul, 69007 Lyon, France
}

\section{ARTICLE INFORMATION}

Received 05 June 2020.

Received in revised form 14 September 2020. Accepted 02 October 2020.

*Corresponding author. Tél : +33 (0)4 78787544 E-mail addresses: brian.chaize@univ-lyon3.fr (Chaize B.)

etienne.cossart@univ-lyon3.fr (Cossart E.)

aurelien.christol@univ-lyon3.fr (Christol A.)

mathieu.fressard@univ-lyon2.fr (Fressard M.)

\begin{abstract}
Vine introduction in Burgundy (east central France) two millennia ago is responsible for land use changes and increased soil erosion to which societies have tried to adapt. In this paper we seek to figure out the relationship between land uses, agricultural practices and geomorphic dynamics in the Mercurey terroir during the Late Holocene. The method employed is based on the analysis of sedimentary deposits observed in the valley bottom and along hillslopes. It is complemented by a pedoanthracological study derived from a trench excavated into a riverbank, in order to interpret the variability of the reconstituted sedimentary signal. Our results highlight two major stages of detritism over the last 2,800 years. At least from $800 \mathrm{cal}$. BC, frost heave screes (stored since the Late Pleistocene) are transported from the upper part of hillslopes to the valley bottom by high-energy geomorphic processes (e.g., solifluction flows). This sequence of coarse colluviums is associated with the development of an agropastoral landscape marked by an opening forest cover. A second phase begins after $1400 \mathrm{cal}$. AD. It is characterized by a fine sedimentation and a high concentration of vine charcoal. Indeed, wine-growing spread in the medieval landscape comes with the building of agricultural infrastructures. It leads to a decrease of sediment connections from the source areas to valley bottom. The coarser sediments are retained on the hillslopes, thus bringing out soil maintenance strategy.
\end{abstract}

Keywords: charcoal, landscape, soil, sedimentary flows, vineyard, Burgundy.

\section{RÉSUMÉ}

L’apparition de la vigne il y a deux millénaires en Bourgogne (Centre-Est de la France) est à l'origine de recompositions paysagères et d'une érosion des sols exacerbée à laquelle les sociétés ont tenté de s'adapter. Dans cet article nous cherchons à démontrer la relation entre les modes d’occupation du sol, les pratiques agricoles et les dynamiques géomorphologiques sur le terroir de Mercurey au cours de l'Holocène récent. La méthode privilégiée repose sur l'examen d'archives morphosédimentaires de fond de vallée et de versant. Elle est complétée par une étude pédoanthracologique, menée sur une coupe stratigraphique de berge, afin d'interpréter la variabilité du signal sédimentaire reconstitué. Les résultats soulignent deux phases majeures de détritisme au cours des 2800 dernières années. Au moins à partir de 800 cal. BC, des éboulis cryoclastiques (stockés depuis la fin du Pléistocène) sont remaniés depuis les hauts de versant jusqu'au fond de vallée par des processus géomorphologiques gravitationnels (e.g., coulées de solifluxion). Ce colluvionnement grossier est associé au développement d'un paysage agro-pastoral marqué par l'ouverture du couvert forestier. Une seconde phase s'amorce après $1400 \mathrm{cal}$. AD. Elle est caractérisée par une sédimentation fine et une concentration élevée en charbons de vigne. En effet, la diffusion de la viticulture dans le paysage médiéval s'accompagne de la mise en place d'aménagements agricoles qui retiennent les sédiments les plus grossiers sur les versants, mettant ainsi en évidence une stratégie de gestion de la ressource en sol.

Mots-clés : charbon, paysage, sol, flux sédimentaire, vignoble, Bourgogne.

\section{Introduction}

Many french palaeoenvironmental studies were led at a regional frame - as a natural region - in order to document society-environmentclimate relationship during the Holocene (Allée and Lespez, 2006; Provansal and Leveau, 2006). Local case studies are nevertheless still required in order to focus on functional systems which involve a wide range of complex drivers and feedbacks between biophysical processes, land uses and human practices (Foucher et al., 2019). Such systemic approach at local scale seeks to document the main types of land uses, their spatial extent, but also stages of evolution and then the drivers underlying this evolution (Foucher et al., 2014).

Amongst the main issues arisen at such medium to local scale, the 
environmental consequences of agricultural activities are currently highly debated. While agricultural activities are commonly considered as an environmental degradation involving an increase of soil losses (Bork and Lang, 2003; van der Leeuw, 2005; Foucher et al., 2014), many studies show that early strategies of soil erosion prevention may have occurred (Tarolli et al., 2014; Larsen et al., 2016). Consequently, the relationship between agricultural intensity and soil erosion is not necessarily linear and a debate arises to discuss whether soil erosion is at maximum during the peak of agricultural intensity or during periods of land abandonment. Such assumptions are based on a hypothesis of soil maintenance strategies during the peak of agricultural activity.

To contribute to the debate on the impact of agriculture on soil losses, a better understanding of the links occurring between landscape characteristics, land use change and sediment delivery is required. One main issue is that such objective depends on past land use spatial information (e.g., aerial imagery) to assess structural hydrosedimentary connectivity within catchments (Foucher et al., 2019; Cossart et al., in press). As a consequence, available studies modelling such interactions are often restricted to the last 40-50 years so that studies led at larger time scales are still lacking (Lasanta et al., 2017).

This study attempts to fill partially this gap of knowledge. We focus here on Burgundy wine-growing area where historical studies suggested a long tradition of soil erosion prevention: some man-made infrastructures such as rough terraces and stony walls have been built since the Early Middle Ages (Garcia et al., 2017a). Such infrastructures are even often considered earlier (possibly dated from Neolithic periods) without any direct chronological evidence (Haasé, 1977; Harfouche, 2017). In this particular biophysical and cultural setting, a reconstruction and subsequent interpretation of the sedimentary signal over millennia can document the complex linkages between land uses and erosion. In detail, geomorphic investigation would help to reach three complementary objectives : (i) sedimentary archives can be examined to document the evolution of soil erosion processes within Burgundy wine-growing area during the last millennia; (ii) by coupling geomorphologic investigations with pedoanthracological study an evolution of land uses can be hypothesized, so that (iii) it can complement scarce palaeoenvironmental data acquired in Burgundy regarding vegetation cover evolution and inferring land uses during the Holocene (Jouffroy-Bapicot, 2010; Laine et al., 2010; Argant et al., 2011). These objectives will permit to define a qualitative model of soil erosion at hillslope scale. Following Clark and Small (1982), we indeed consider hillslopes as a natural system within which there are numerous complex linkages and interactions between controlling factors, processes and forms. Investigation at such scale is thus well suited to illustrate what can be the complex interactions between land uses and erosion patterns.

The Côte Chalonnaise area and the Mercurey terroir fit well with all of these objectives. On the one hand, during the last decades manmade infrastructures and the evolution of land use spatial patterns have directly influenced the level of soil erosion rates (Fressard et al., 2017; Fressard and Cossart, 2019) revealing strategies to prevent soil erosion (Cossart et al., in press). On the other hand, this area remains poorly documented from palaeoenvironmental point of view. Finally, Mercurey area has well-shaped geomorphic units in which sediment stores allow us to identify clear records in sedimentary archives.

Such sediment archives are studied to draw some hypotheses on the coevolution of land uses and geomorphic systems to discuss to what extent some soil maintenance strategies were early applied.

\section{Study area}

\subsection{Physical settings}

We focus on the Giroux catchment $\left(15 \mathrm{~km}^{2}\right)$ where Mercurey vineyards (640 ha) are located (Côte de Bourgogne, Burgundy, France). The Côte de Bourgogne (i.e., from the Côte de Nuits

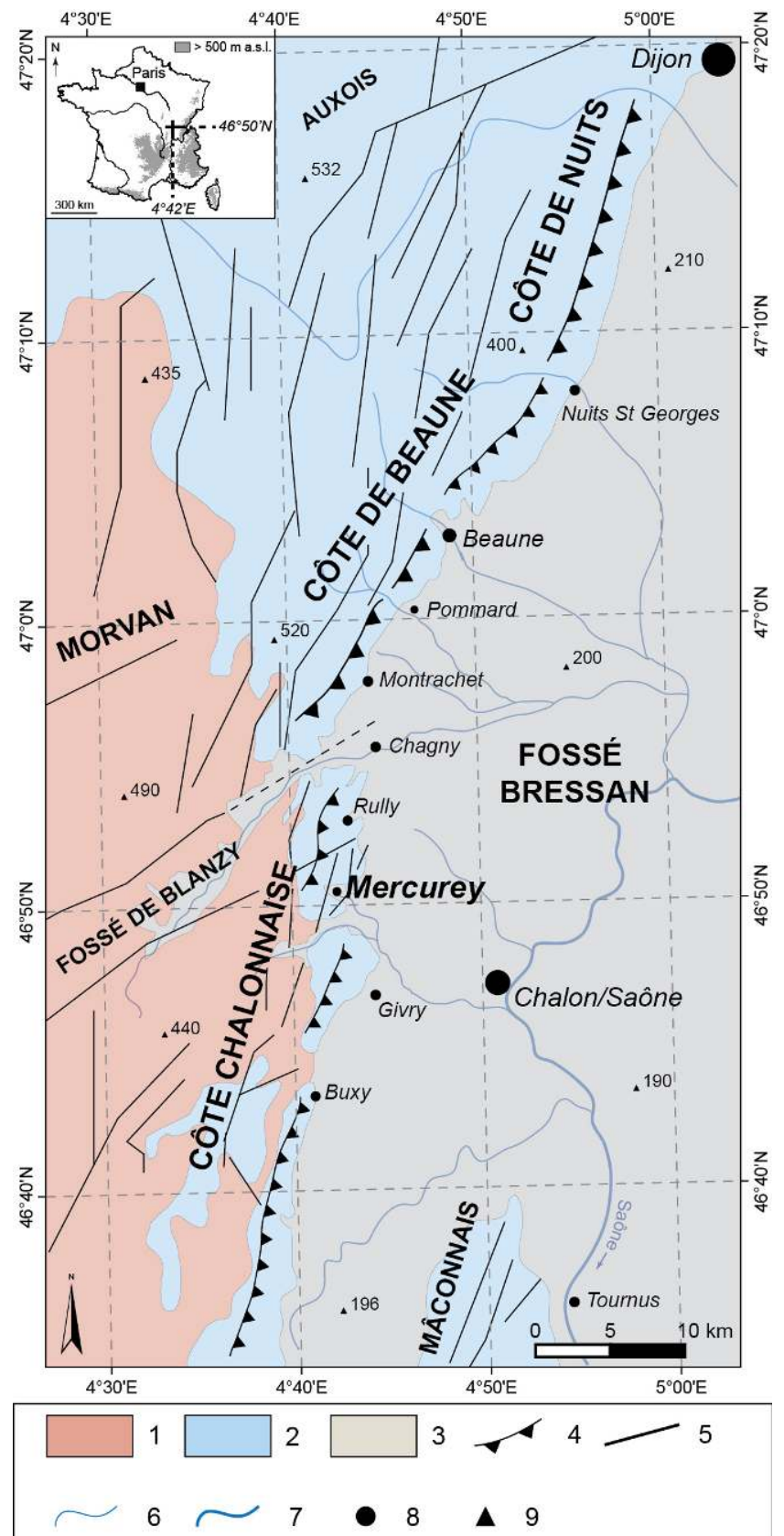

Fig. 1 - Geomorphological sketch of the Côte de Bourgogne (adapted from Fressard et al., 2017).

1. Ante-Devonian crystalline bedrock; 2. Jurassic carbonate sedimentary cover; 3. Quaternary alluvial deposits; 4. Main fault scarps (talus); 5 . Main fault lines; 6 . Stream of the $1^{\text {st }}, 2^{\text {nd }}$ and $3^{\text {rd }}$ Strahler orders; 7 . Stream of the $4^{\text {th }}$ Strahler order; 8 . Major localities; 9. Spotted height.

Fig. 1 - Croquis morphostructural de la Côte de Bourgogne (modifié d'après Fressard et al., 2017).

1. Socle cristallin anté-dévonien; 2. Couverture sédimentaire carbonatée jurassique ; 3. Alluvions quaternaires; 4. Principaux escarpements de faille (talus); 5. Principales lignes de faille; 6 . Cours d'eau d'ordre Strahler 1, 2 et 3; 7. Cours d'eau d'ordre Strahler $4 ; 8$. Principales localités; 9 . Cote altimétrique. 
northward to the Côte Chalonnaise southward) is a structural escarpment set on a NNE-SSW fault line that subdivides the Morvan massif (horst) and the Saône floodplain (graben). The hillslope morphology is very similar throughout the escarpment and is characterized by an Oxfordian limestone outcrop at the top (from 20 to $70 \mathrm{~m}$ high) and a well-shaped concave profile at the bottom (Oxfordian marl or marly limestones) (fig. 1). Catchment geometry enabled the storage of sedimentary sequences that recorded past environments. The geomorphic evolution since the Late Quaternary period generated sediments infill made of colluvial brown limestone soils on the hillslopes, while the plains were mostly filled by silt and clay (Mériaux et al., 1981; Campy, 2017). These colluviums are supplied by bedrock weathering from the sediment sources located in the upper part of hillslopes and on plateaus (Ciry, 1951, 1959; Rat, 1953). Colluvial deposits reveal periglacial patterns such as cryoturbation patterns (Chaline, 1976; Leneuf and Puisségur, 1976). In many areas of Côte de Bourgogne, hillslope screes are observed at the foot of rocky faces made of limestones and are interpreted as the result of frost heave during Pleistocene periglacial stages. Locally, some large amount of boulder and pebbly materials are observed along slide surfaces, showing that some large mass-movement may have occurred at that time (Brenot, 2007).

Within the Giroux catchment area, we have selected a section where the valley is particularly narrow, offering a direct coupling between the valley bottom, hillslopes and plateaus. We can thus document the geomorphic evolution of a sediment cascade through a "source-to-sink" approach. Located upstream of the Pont Latin pond, this valley stretch is one kilometer wide, and shows preserved sedimentary assemblages both on hillslopes and in valley bottom. In detail, the hillslope is approximately 60 to $80 \mathrm{~m}$ high, and ranges from 0.4 to $0.5 \mathrm{~km}$ length. The slope gradients reach $25^{\circ}$ to $35^{\circ}$ in the upper part of the hillslopes (limestone ledge), and gradually decrease near the thalweg where the slope gradient is less than $3^{\circ}$ (fig. 2). Commonly dried throughout the year, the Giroux valley stretch studied may occasionally undergo major summer flash floods.

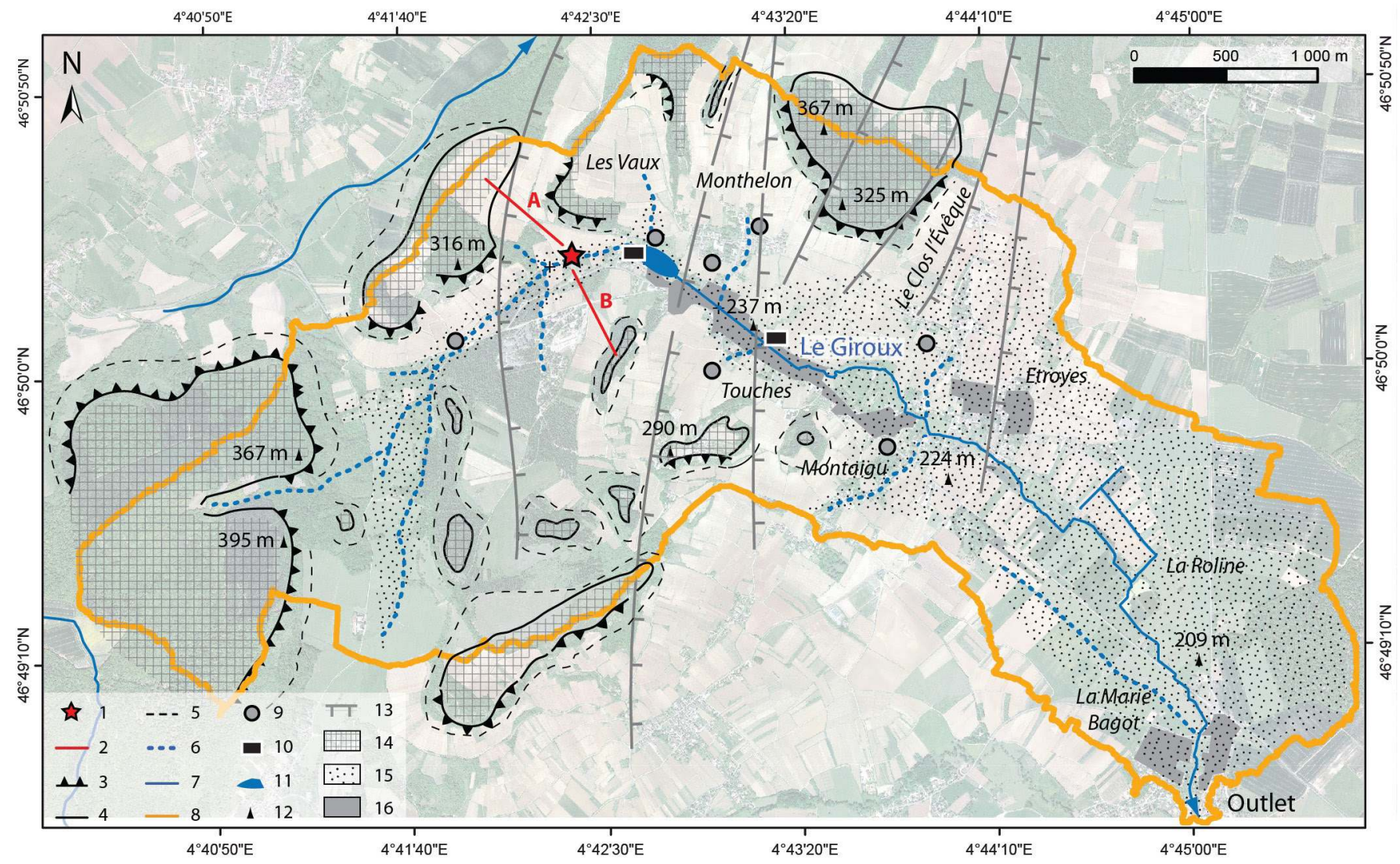

Fig. 2 - Geomorphological sketch of the Giroux catchment (background aerial photography, IGN 2013; adapted from Fressard et al., 2017).

1. Study trench; 2. Hillslope profiles studied; 3. Limestone ledge; 4. Convex break of slope; 5 . Concave break of slope; 6. Temporary streams; 7. Main streams; 8. Giroux catchment area; 9. Sediment trap; 10. Storm basin; 11. Pond; 12. Spotted height; 13. Main faults lines; 14. Plateau surface; 15. Alluvial plain; 16. Urban area.

Fig. 2 - Croquis géomorphologique du bassin versant du Giroux (photographie aérienne en arrière-plan, IGN 2013 ; modifié d'après Fressard et al., 2017). 1. Coupe étudiée; 2. Topo-séquences de versant étudiées; 3. Corniche calcaire; 4. Rupture de pente convexe (haut de versant); 5 . Rupture de pente concave; 6. Réseau hydrographique intermittent ; 7. Réseau hydrographique principal; 8. Limite du bassin versant; 9. Bassin de décantation; 10. Bassin d'orage; 11. Étang; 12. Cote altimétrique; 13. Principales lignes de faille; 14. Plateau calcaire; 15. Plaine alluviale; 16. Zone bâtie.

\subsection{Archaeological background}

We have listed 394 archaeological sites from the Bronze Age to the Middle Ages on the Mercurey region. Protohistorical data are scanty and mainly distributed along river network, which was certainly a region economic driver (fig. 3A-B). Permanent occupations (e.g, fortified sites) is an indirect evidence of land use for agricultural purposes (Dubouloz et al., 2017). Findings of domestic furniture (a large storage vase and a millstone) dated from the Iron Age may be linked to technological evolutions and agricultural activities (tab. 1).

For the Gallo-Roman times, a significant increase of sites is 


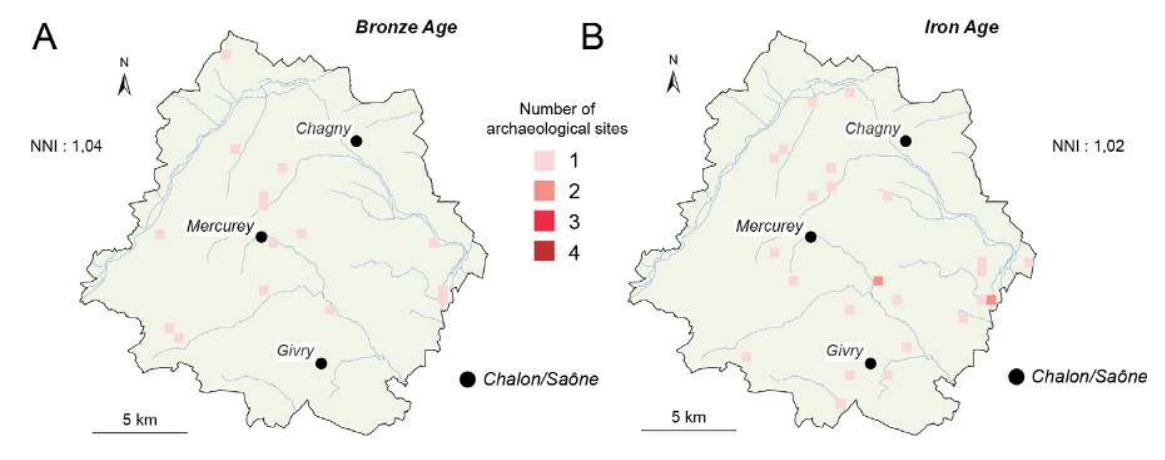

Fig. 3 - Archaeological sites inventory of the Mercurey region through the Late Holocene (data from SRA BourgogneFranche-Comté, Patriarche database, July 2020).

Chronological maps are based on the frequency of archaeological sites per surface unit of $500 \mathrm{~m}^{2}$. A: Bronze Age; B.: Iron Age; C: GalloRoman times; D: Middle Ages. NNI: Nearest neighbour index.

Fig. 3 - Recensement des sites archéologiques de la région de Mercurey au cours de l'Holocène récent (données SRA Bourgogne-Franche-Comté, base de données Patriarche, juillet 2020).

Les cartes chronologiques sont basées sur la fréquence des sites archéologiques par unité de surface de $500 \mathrm{~m}^{2}$. A : Âge du Bronze ; B : Âge du Fer ; $C$ : Époque gallo-romaine; $D$ : Moyen Âge. NNI : Indice du plus proche voisin.

recorded (fig. 3C). Many are located near two main roads: the first (known as the Agrippa road) connected Chalon-sur-Saône and its fluvial merchant port to the great ancient city of Autun; the second went from Beaune to Mâcon. These roads crossed the Mercurey territory. A pit silo dated to Early Roman Empire suggests land use for agricultural needs. Although there is not archaeological evidence of vine growing during this period, the Mercurey region is located at the crossroads of numerous sites known to have provided data linked with the Gallo-Roman viticulture (wine amphora, grape growing tools, planting pit, etc.) (Goguey, 1970; Planson, 1970; Huygen, 1988; Vernou, 2009; Garcia et al., 2010) (fig. 4).

Compared with the previous period, the medieval sites are slightly less numerous but better spatially distributed (fig. 3D). In detail,

Tab. 1 - Archaeological entities of the Mercurey region (data from SRA Bourgogne-Franche-Comté, Patriarche database, July 2020).

Tab. 1 - Entités archéologiques de la région de Mercurey (données SRA Bourgogne-Franche-Comté, base de données Patriarche, juillet 2020).

\begin{tabular}{|c|c|c|c|c|}
\hline & Bronze Age & Iron Age & Gallo-Roman & Middle Ages \\
\hline Communication & 0 & 0 & 21 & 0 \\
\hline $\begin{array}{l}\text { Cultural and } \\
\text { religious }\end{array}$ & 0 & 1 & 8 & 40 \\
\hline Currency & 0 & 0 & 3 & 2 \\
\hline Handicraft & 0 & 0 & 1 & 2 \\
\hline Funerary & 3 & 6 & 23 & 34 \\
\hline Settlement & 12 & 17 & 135 & 81 \\
\hline Agriculture & 0 & 2 & 1 & 1 \\
\hline Total & 15 & 26 & 193 & 160 \\
\hline
\end{tabular}

many castles were built but also a large number of churches and monasteries were founded at the instigation of the Cluny Abbey especially, suggesting an economic and demographic growth. Local laws on vine grubbing-up to reduce overproduction crisis revealed an intensive landscape and soil management during the Late Middle Ages (Beaulant, 2018).

\subsection{Holocene vegetation changes}

We can describe the main stages of the regional landscape evolution since the beginning of the Neolithic through a synthesis of palynological data (Jouffroy-Bapicot, 2010; Laine et al., 2010; Argant et al., 2011). Such data are sometimes complemented with other palaeoenvironmental studies. Available data are acquired on sites distributed in the Morvan massif, along the Côte de Bourgogne, in the Saône floodplain and the Jura piedmont (fig. 5). These sites frame the study area, which enables comparison with the data produced in this paper. Chronological sequences are here based on the major chronozones of the Holocene established by Mangerud et al. (1974).

The Atlantic chronozone (7000 to $3700 \mathrm{cal}$. BC) coincides with the first signs of human impacts around $4900 \mathrm{cal}$. BC, as indicated by the emergence of cultivated species (Triticum, Hordeum, Avena) into the Saône floodplain and the Morvan massif (fig. 6). Their introduction is made possible by the clearings of a mesothermophilous forest composed of oak (Quercus), elm (Ulmus), ash (Fraxinus), lime (Tillia) and hazel (Corylus). Alder (Alnus) is the dominant species in valley bottoms. Herbaceous species (e.g., Plantago, Urticaceae) emerge with the opening of the forest for agro-pastoral needs. Taking advantage of cooler and wetter climatic conditions at the beginning of Subboreal (Haas et al., 1998; Magny and Haas, 2004; Magny, 2013), beech (Fagus) grows around $3500 \mathrm{cal}$. BC. It occupies a predominant proportion in the forest cover during the Subboreal (3700 to $800 \mathrm{cal}$. BC).

The Subatlantic period (since $800 \mathrm{cal}$. BC) is characterized in one 


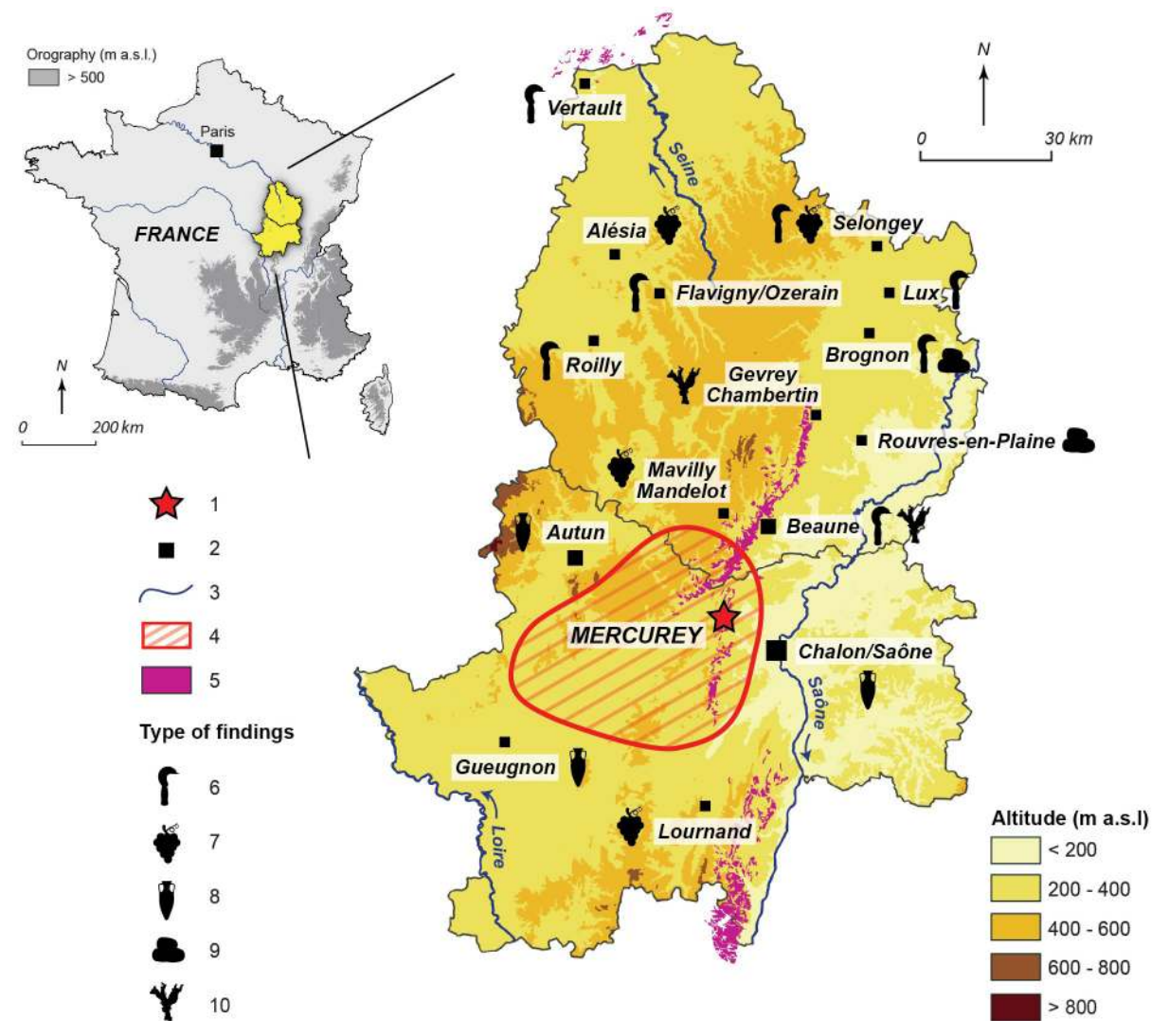

Fig. 4 - Gallo-Roman viticulture evidences in Burgundy.

1. Study site; 2. Localities; 3. Main streams; 4. Area undocumented; 5. Current Burgundy vineyard; 6 . Grape growing tools; 7. Ecofacts (grape seeds, pollens, woody macro-remains); 8. Wine amphora; 9. Planting pit; 10 . Villa with vinification cellar.

Fig. 4 - Indices de viticulture galloromaine en Bourgogne.

1. Site d'étude; 2. Localités; 3. Principaux cours d'eau; 4. Zone non documentée; 5. Extension actuelle du vignoble bourguignon; 6 . Outillage viticole; 7. Écofacts (pépins, pollens, macro-restes ligneux) ; 8. Amphore vinaire ; 9. Fosse de plantation; 10. Villa à descente de cave.

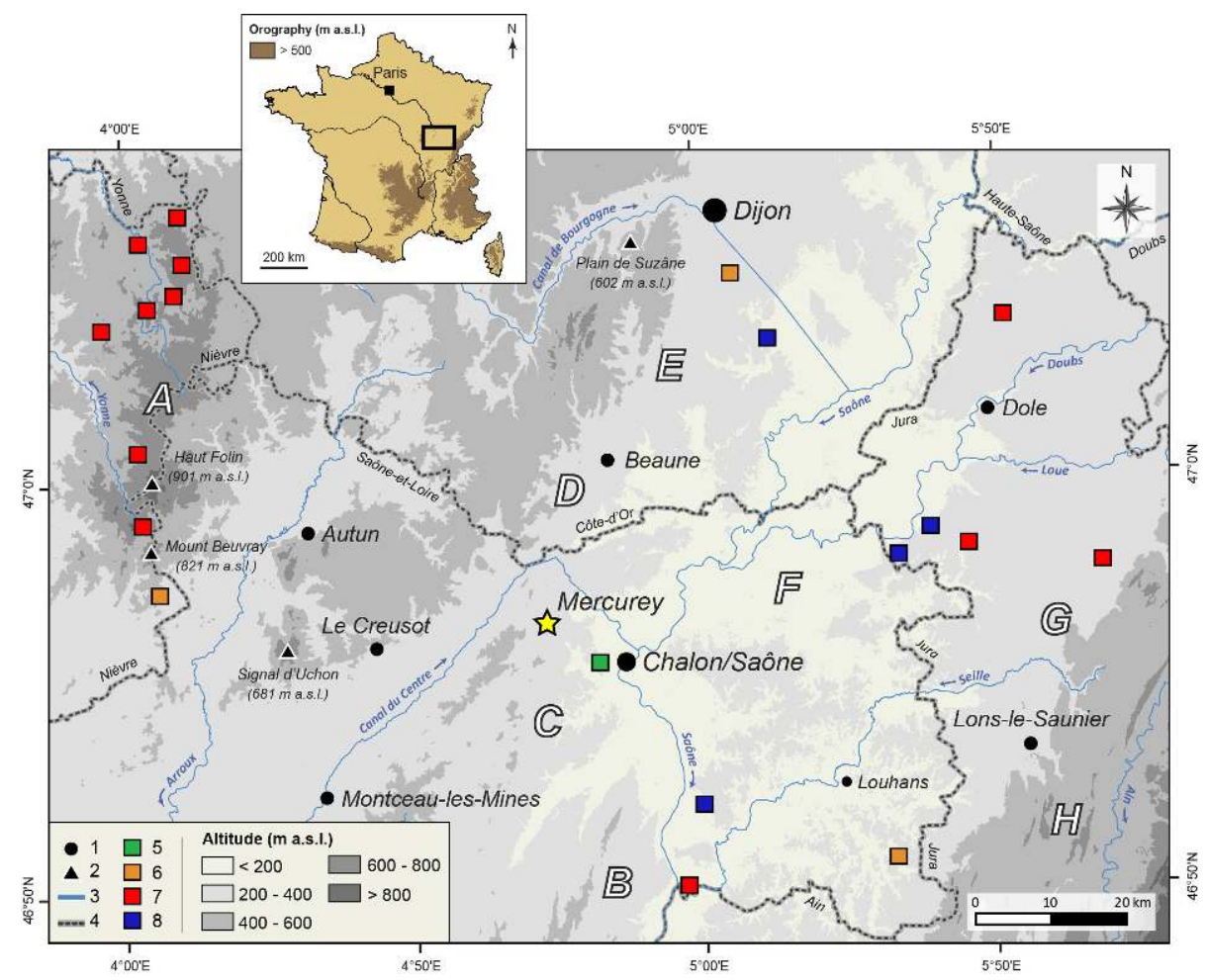

Fig. 5 - Palynological studies on the Côte de Bourgogne and its margins (Morvan massif, middle Saône valley and Jura piedmont). Studies are ordered according to the background where they have been made.

1. Major localities; 2. Main mountain peaks; 3. Main streams; 4. Administrative boundaries; 5. Archaeological site; 6. Swamp; 7. Peatland; 8. Palaeochannel. A: Morvan massif; B: Mâconnais; C: Côte Chalonnaise; D: Côte de Beaune; E: Côte de Nuits; F: Middle Saône valley; G: Jurassian vineyard; H: Revermont / Jura plateaus.

Fig. 5 - Études palynologiques sur la Côte de Bourgogne et ses marges (massif du Morvan, moyenne vallée de la Saône et piémont du Jura). Les études ont été classées selon le contexte dans lequel elles ont été réalisées.

1. Principales villes; 2. Principaux sommets : 3. Principaux cours d'eau ; 4. Limites administratives ; 5 . Site archéologique ; 6 . Marais ; 7. Tourbière ; 8. Paléochenal. A Massif du Morvan ; B : Mâconnais ; C : Côte Chalonnaise ; D : Côte de Beaune ; E : Côte de Nuits ; F : Moyenne vallée de la Saône ; $G$ Vignoble jurassien; H : Revermont / Plateaux du Jura.

hand by the appearance of hornbeam (Carpinus) around $800 \mathrm{cal}$. BC (Richard, 1999), and on the other hand by the introduction of new cultivated species such as walnut (Juglans) and chestnut (Castanea) around $200 \mathrm{cal}$. BC. Shortly afterwards, a new speculative plant was cultivated: according to pollen analysis and archaeological data, vine (Vitis vinifera) appeared in Burgundy and the Jura piedmont during Gallo-Roman times (Gauthier, 2000; Gauthier and Joly, 2003; Garcia et al., 2010). The anthropogenic impact on the plant assemblages and land cover has globally increased since the $6^{\text {th }}$ millennium BC (Early Atlantic) and has intensified during the Late Holocene. Around $900 \mathrm{cal}$. AD, hemp (Cannabis) and rye (Secale) appeared alongside traditionally cultivated cereals (wheat, 


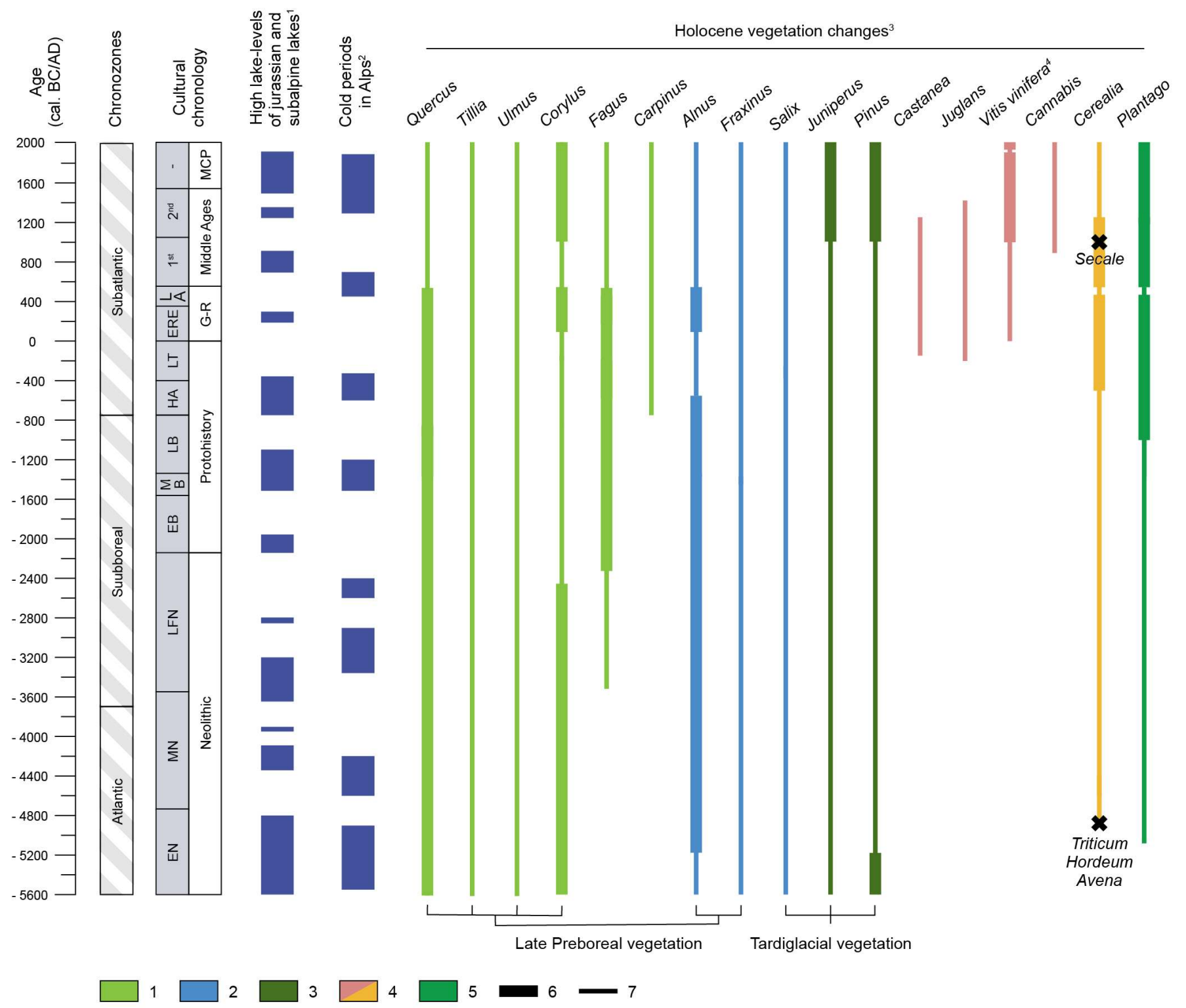

${ }^{1}$ Magny, 2004; ${ }^{2}$ Haas et al., 1998; ${ }^{3}$ Jouffroy-Bapiquot, 2010; Laine et al., 2010; Argant et al., 2011; ${ }^{4}$ Dion, 2010; Garcia et al., 2010

Fig. 6 - Simplified synthesis of regional palaeoenvironmental data since the Neolithic.

1. Plain / hill forest; 2. Humid vegetation; 3. Dryland vegetation; 4. Cultivated plants; 5 . Grassland; 6. Strong signal in regional palynological diagrams; 7. Low signal in regional palynological diagrams. EN: Early Neolithic; MN: Middle Neolithic; LFN: Late and Final Neolithic; EB: Early Bronze Age; MB: Middle Bronze Age; LB: Late Bronze Age; HA: Hallstatt ( $1^{\text {st }}$ Iron Age); LT: La Tène ( $2^{\text {nd }}$ Iron Age); ERE: Early Roman Empire; LA: Late Antiquity; G-R: Gallo-Roman period; MCP: Modern and Contemporary period.

Fig. 6 - Synthèse simplifiée des données paléoenvironnementales régionales depuis le Néolithique.

1. Forêt de plaine et de versant; 2. Végétation humide; 3. Végétation de milieu sec; 4. Plantes cultivées; 5 . Végétation prairiale ; 6 . Signal fort dans les diagrammes polliniques régionaux; 7 . Signal faible dans les diagrammes polliniques régionaux. EN : Néolithique ancien; $M N$ : Néolithique moyen; LFN : Néolithique récent et final; EB: Bronze ancien; $M B$ : Bronze moyen; LB : Bronze final; HA : Hallstatt (1 $1^{\text {er }} \hat{g}$ ge du Fer) ; LT : La Tène (2 éme âge du Fer); ERE : Haut-Empire romain; LA : Antiquité tardive; G-R : Époque gallo-romaine; MCP : Époque moderne et contemporaine.

barley, oats) in the Morvan massif and floodplain area while vine cultivation spreads in the Burgundian landscape (Garcia, 2014). Concerning forest cover, from $500 \mathrm{cal}$. AD, trees tend to shrink (oak and beech in particular). Only heliophilous species are progressing (Pinus, Corylus, Juniperus), which reveals a transition to an open landscape. In the Late Subatlantic, on the one hand the assemblage of trees has hardly changed, on the other hand cereal crops have become scarcer in favor of thriving prairie plants.

\section{Materials and methods}

\subsection{Identification of sedimentary facies and associated processes}

This study focuses on hillslopes considered a functional system involving complex feedbacks between biophysical processes, land uses and human practices. From a geomorphic field survey, we detailed geomorphic components along hillslope profiles: 

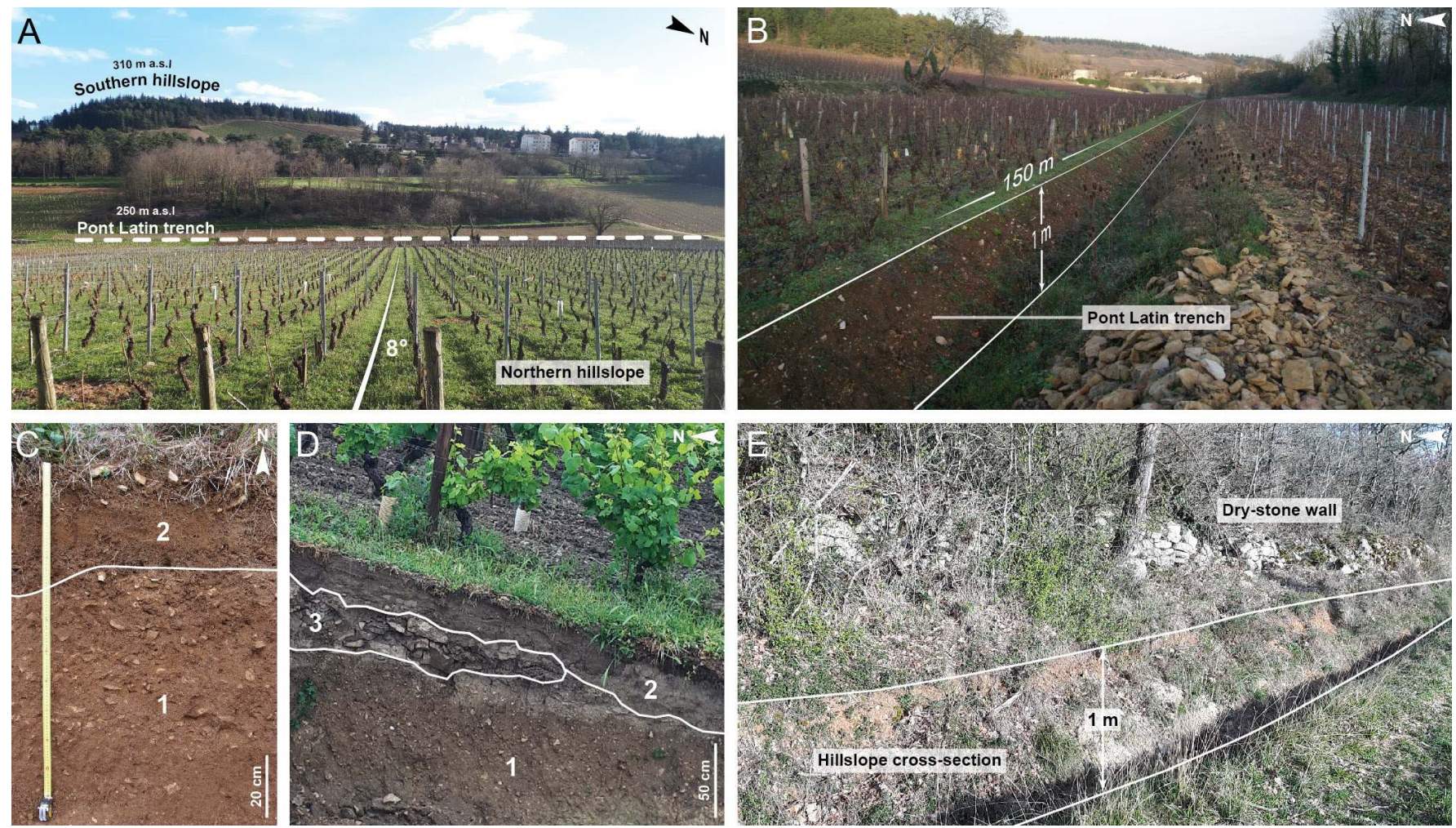

Fig. 7 - Photographs of Pont Latin site and main sedimentary deposits studied.

A. General overview of the Pont Latin site; B. Longitudinal view of the Pont Latin trench. Note that the trench is located at the contact of the northern hillslope; C. Major sedimentary aggradation phases from profile A of the Pont Latin trench. 1. Unsorted deposit made of angular limestone clasts (many centimeters) within a silty-clayey matrix; 2. Fine matrix (clayey silts) with roughly bedding patterns. D. Cross-section of colluvial deposits located 40 meters above the thalweg. 1. Unsorted deposit made of angular clasts (many centimeters) within a silty-clayey matrix; 2. Fine matrix (silt and clay) with rough stratification parallel to hillslope topographic surface; 3 . Wall remnant. E. Cross-section of colluvial deposits located 30 meters above the thalweg and topped with an old dry-stone wall. (photo credit: B. Chaize, 2019 and 2020).

Fig. 7 - Photographies du site du Pont Latin et des principaux dépôts sédimentaires étudiés.

A. Vue d'ensemble du site du Pont Latin; B. Vue longitudinale de la coupe du Pont Latin. Notez que la coupe est située au contact du versant nord; C. Principales phases d'aggradation sédimentaire du profil A de la coupe du Pont Latin. 1. Dépôt massif de clastes calcaires anguleux pluricentimétriques dans une matrice limono-argileuse; 2. Matrice fine (limons argileux) avec une structure grossièrement litée. D. Coupe transversale de dépôts colluviaux située 40 mètres au-dessus du talweg. 1 . Dépôt massif de clastes anguleux pluricentimétriques dans une matrice limono-argileuse; 2. Matrice fine (limons argileux) avec une stratification grossière parallèle à la surface topographique; 3 . Vestige d’un mur. E. Coupe transversale de dépôts colluviaux située 30 mètres au-dessus du talweg et surmontée par un mur de pierres sèches délabré. (crédit photographique : B. Chaize, 2019 et 2020).

topography, bedrock outcrops, sedimentary stores (e.g., material fabrics of surficial deposits), anthropogenic infrastructures (e.g., ditches, hedges, walls) and landforms at fine scale (e.g., scree, gullies). We particularly examine sedimentary archives, from which we seek to reconstruct the man/soil system and its evolution. This examination is mostly based on the analysis of the Pont Latin trench located in the valley bottom, at the foot of hillslopes to which it is directly connected (fig. 7A-B). It was dug in 2016 to channelize Giroux river seasonal floods and topographic runoff towards a storm basin and the Pont Latin pond located $300 \mathrm{~m}$ further downstream. Studied trench (approximately $150 \mathrm{~m}$ long) was decomposed into a series of five regularly spaced vertical profiles to follow vertically and horizontally (east-west) variations of each stratigraphic unit (fig. 7C). To complement this sedimentary data, we performed an inventory and a qualitative description of eight cross-sections from which we can observe sediment sources and sediment stores along two hillslope profiles (fig. 7D-E).

Sedimentary units were described regarding their facies (structure, texture, color) to determine the geomorphic process responsible for their deposition (Miall, 1985). In detail, we particularly looked at the respective volumetric proportions of clasts that form the framework (e.g., gravel, pebble, cobble) and detrital sediment that is the matrix.
The framework is described in terms of shape of individual clasts (e.g., angular, subangular, rounded). The proportions of different clast sizes (e.g., sorting), and the proportion of framework corresponding to matrix are also assessed. Collectively, these data provide information on the degree of sediment reworking during transport (e.g., rounded clast following alluvial transport, angular clast following gravityfed transport), and on depositional energy. For instance, larger and unsorted clasts are observed in case of higher energy processes involved in colluvial deposition (Bertran, 2004). Sedimentary fabric may complement the interpretation by documenting directionality of clasts and sediment structures. For instance, colluvial processes such as sliding and flowing mostly generate en masse deformations, leading to diamictites without any inner clasts organization that contrast with better organized (stratification and sorting) materials deposited by alluvial processes.

\subsection{Pedoanthracology}

Pedoanthracology determines charcoal fragment taxa from a natural context. It can be used to give information about past woody vegetation dynamics (Touflan et al., 2010). 


\subsubsection{Inputs from pedoanthracology}

Charcoal have several advantages for documenting Mercurey past environments. Firstly, they are a major source of information to trace wooded areas management over time because they make it possible to determine woody vegetation that was burnt by human societies (Dambrine et al., 2007; Dutoit et al., 2009; Bal et al., 2015). In detail, charcoal may be subdivided in three types: charcoal from forest formations, charcoal from riparian areas and charcoal of speculative species (fig. 8). Trees from forest covers may be burnt from either natural or anthropogenic drivers. In that case we particularly look at the occurrence of heliophilous species that may reveal forest clearance and a possible anthropogenically-driven maintenance in a context of spatial extension of agriculture and grazing (Dutoit et al., 2009; Bal et al., 2015). In riparian context, trees are often burnt to clear the riparian forest to have an easier access to the river. It also enables the ecological maintenance of the river (Delhon, 2005). Charcoal of speculative plants more directly document what were the vegetal and agricultural resources on which societies focused (ibid.). Chestnut or olive tree exemplifies this speculative type. Vine charcoal may be considered either riparian (Vitis vinifera subsp. sylvestris) or speculative (Vitis vinifera subsp. vinifera). To ensure vine charcoal reveals a speculative plant, we have to check whether vines were located on hillslopes where Vitis sylvestris cannot grow. Vine development history in Mercurey can thus be documented because vine is a shrub whose annual pruning provides large quantities of wood which have been burnt since Gallo-Roman times (Amouretti, 1988). Carbonized residues may be a direct marker of vine-growing over long time. Secondly, they offer a very fine spatial resolution because charcoal larger than $0.4 \mathrm{~mm}$ (minimum size for taxonomic identification) cannot be transported over long distances and therefore represent local woody vegetation (Lynch et al., 2004; Peters and Higuera, 2007; Dutoit et al., 2009). Thirdly, under all environmental conditions soils preserve charcoal very well and for a long time (de Lafontaine and Asselin, 2011). Moreover, anthracological data on the evolution of northern French vineyard landscapes are still very scarce (Zech-Matterne et al., 2011).

\subsubsection{Analytical protocol}

Charcoal analysis follows the protocol described by Delhon (2005). In each of the five profiles studied, a sample of eight liters of sediment was extracted in the middle of each sedimentary unit, starting from the basal unit to avoid contamination. Moreover,

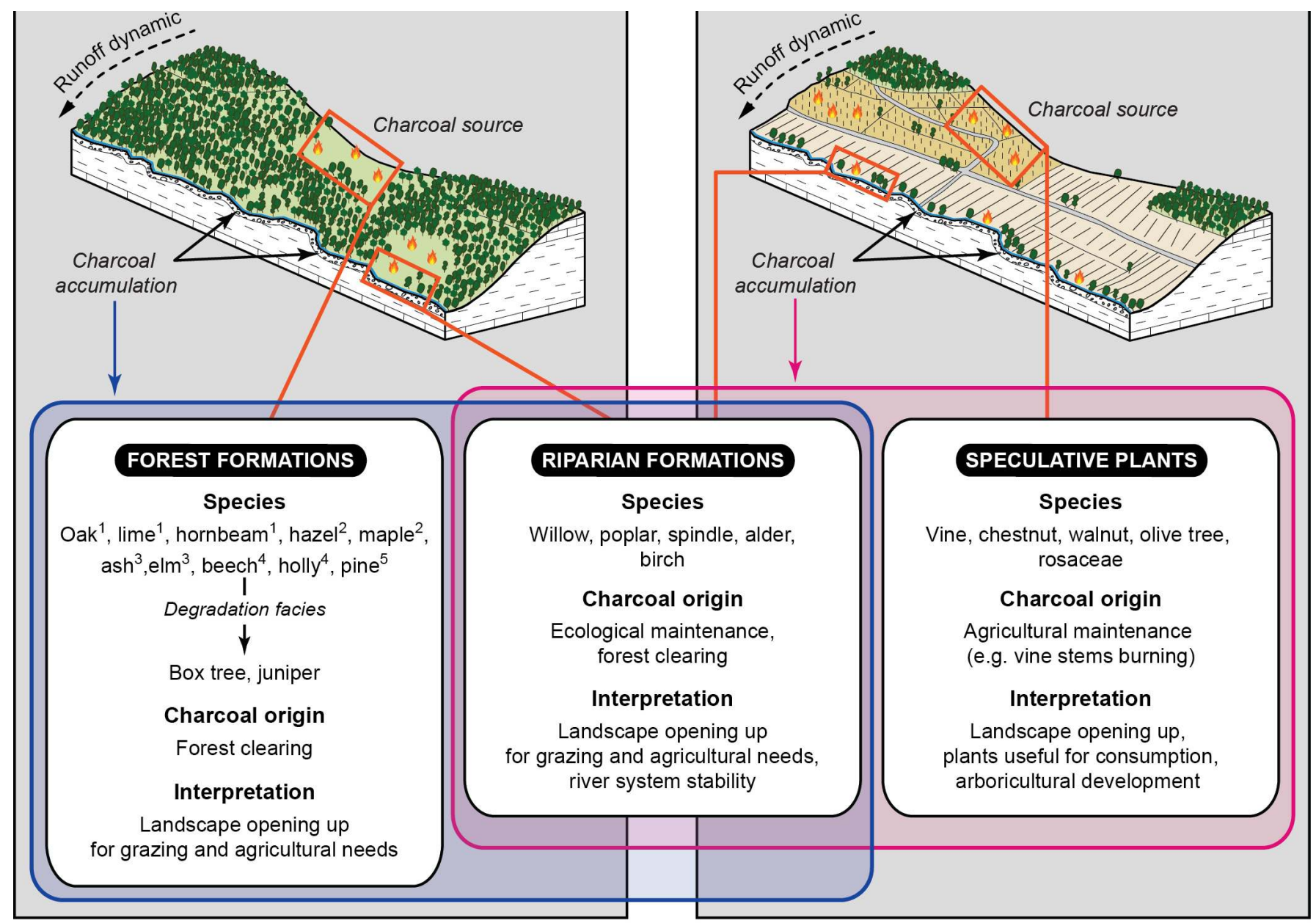

1. Deciduous oak grove; 2. Heliophilous; 3. Semi-hygrophilous; 4. Moist mountain climate; 5. Dry mountain climate

Fig. 8 - Interpretative framework of pedoanthracological data at hillslope scale.

Fig. 8 - Éléments d'interprétation des données pédoanthracologiques à l'échelle du versant. 
some macro-charcoal is randomly sampled on the field by taking care to label them according to their position. In laboratory, samples were deflocculated in a hot water bath for $48 \mathrm{~h}$ with a solution of sodium hexametaphosphate and mixed in a magnetic agitator to break micro-aggregates. Then, charcoal were collected manually by systematic sieving at $2 \mathrm{~mm}$ and $500 \mu \mathrm{m}$ of mixed
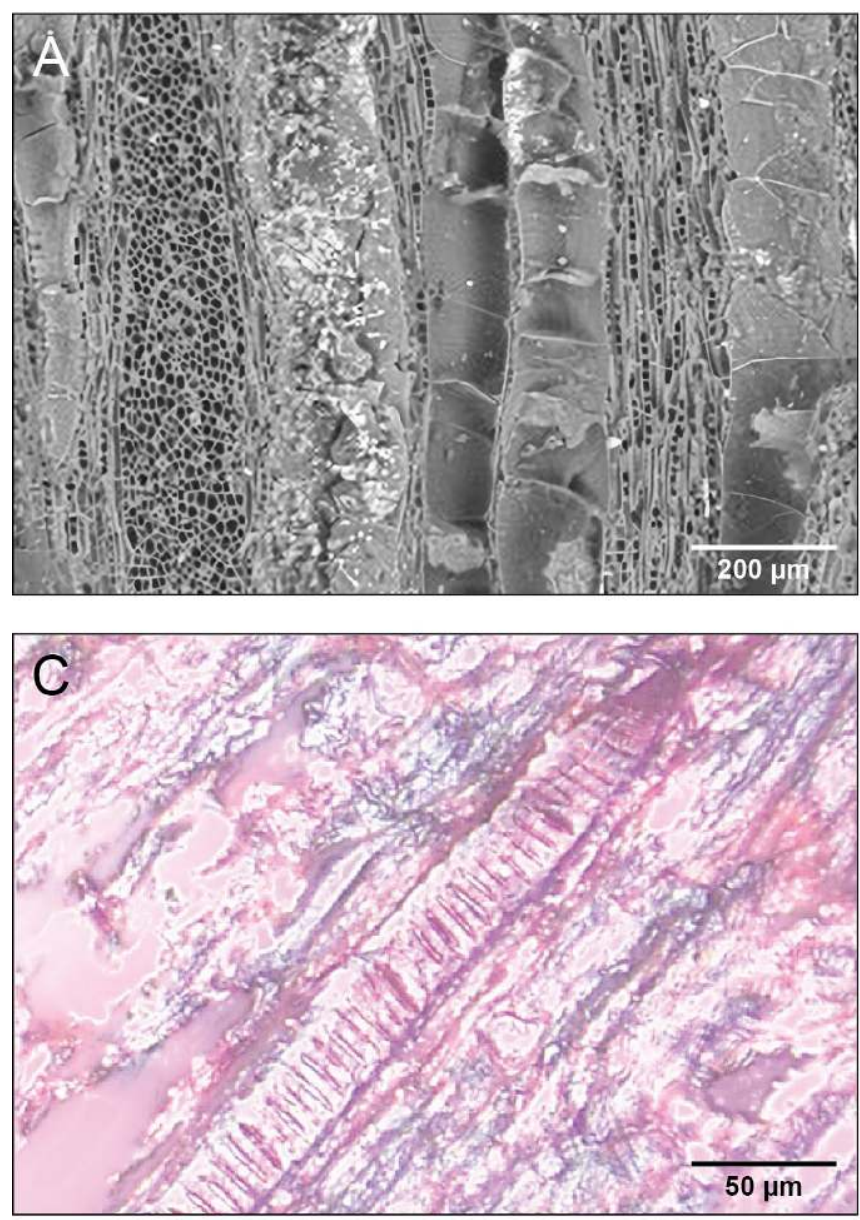

Fig. 9 - Microscopic views of charcoal from the Pont Latin trench.

A: Longitudinal tangential plan of oak (Quercus sp.); B: Transverse plan of a Scots pine (Pinus sylvestris); C: Longitudinal tangential plan of vine (Vitis sp.); D: Transverse plan of hazel (Corylus avellana). (photo credit: Chaize, 2019).

Fig. 9 - Vues microscopiques de charbons issus de la coupe du Pont Latin.

A : Plan longitudinal tangentiel de chêne (Quercus sp.); B : Plan transversal de pin sylvestre (Pinus sylvestris); C: Plan longitudinal tangentiel de vigne (Vitis sp.); D : Plan transversal de noisetier (Corylus avellana). (crédit photographique: Chaize, 2019).

longitudinal radial), was identified at the finest possible taxonomic level (usually species or genus) by observation of the anatomical structures (fig. 9A-D). The observation was conducted under a reflection optical microscope and by comparison with those described in wood anatomy atlases (Schweingruber, 1990; Vernet et al., 2001) and charcoal from a reference collection. Identified charcoal is reported in a counting table showing frequencies per taxa and per profile (see section 4.2.).

\subsection{Radiocarbon dating}

The chronological control is based on nine Accelerator Mass Spectometry (AMS) radiocarbon dating obtained on charcoal, some of which have been identified. Radiocarbon ages were calibrated materiel. We deleted charcoal fragments smaller than $500 \mu \mathrm{m}$ which are too small to allow taxonomic identification. Once airdried, they were sorted under a binocular magnifier to dissociate them from the other remains or the mineral elements present in the sieve rejects. Each fragment, previously fractured by hand, ideally along the three woody planes (transverse, longitudinal tangential,
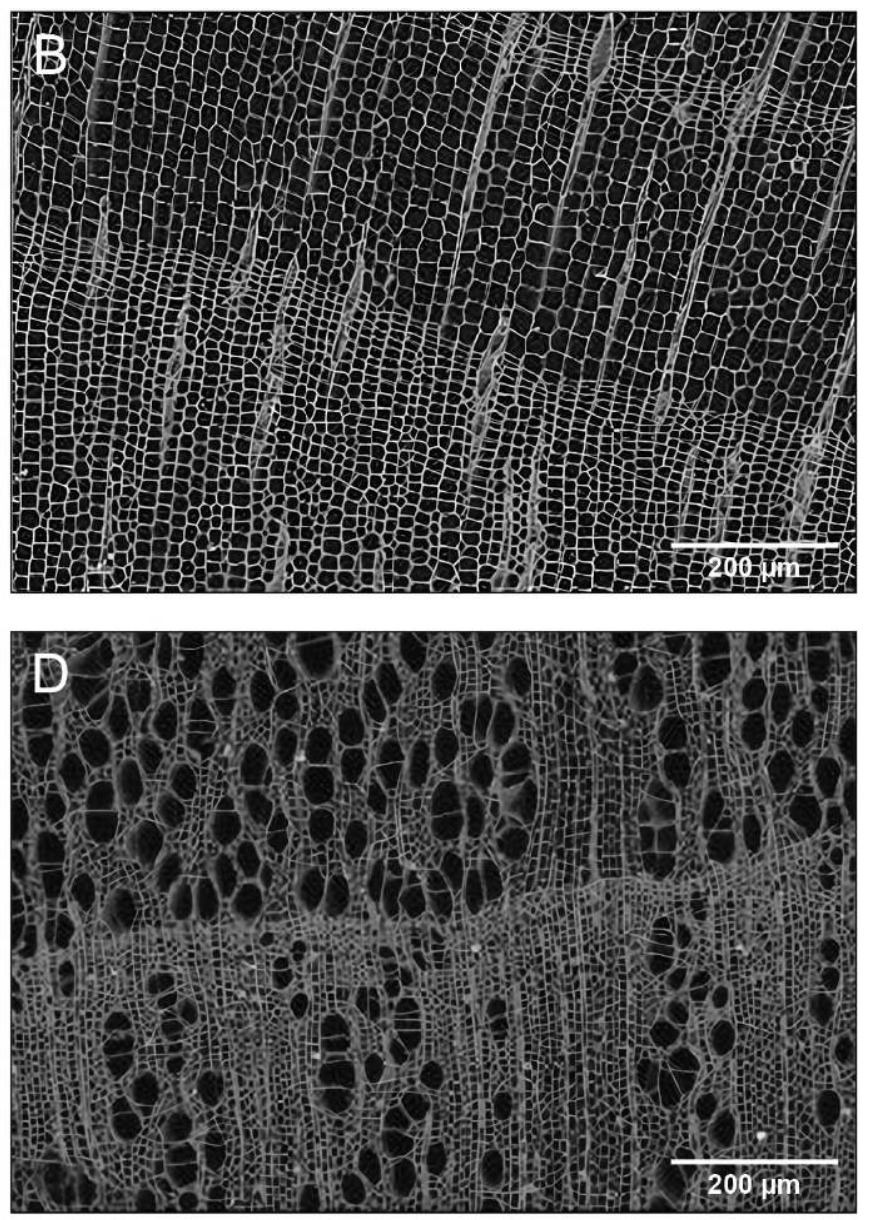

with a $99.7 \%$ confidence interval $(2 \sigma)$ and expressed as cal. BC/AD, by using the program $\mathrm{OxCal} 4.3$ and the calibration curve IntCal13 (Reimer et al., 2013).

\section{Results}

\subsection{Sedimentary records}

\subsubsection{Hillslopes}

Two hillslope profiles have been performed from the compilation of all cross-sections described on southern and northern hillslopes of the Pont Latin site (fig. 10A-B).

The southern hillslope is dominated by concave topography due 

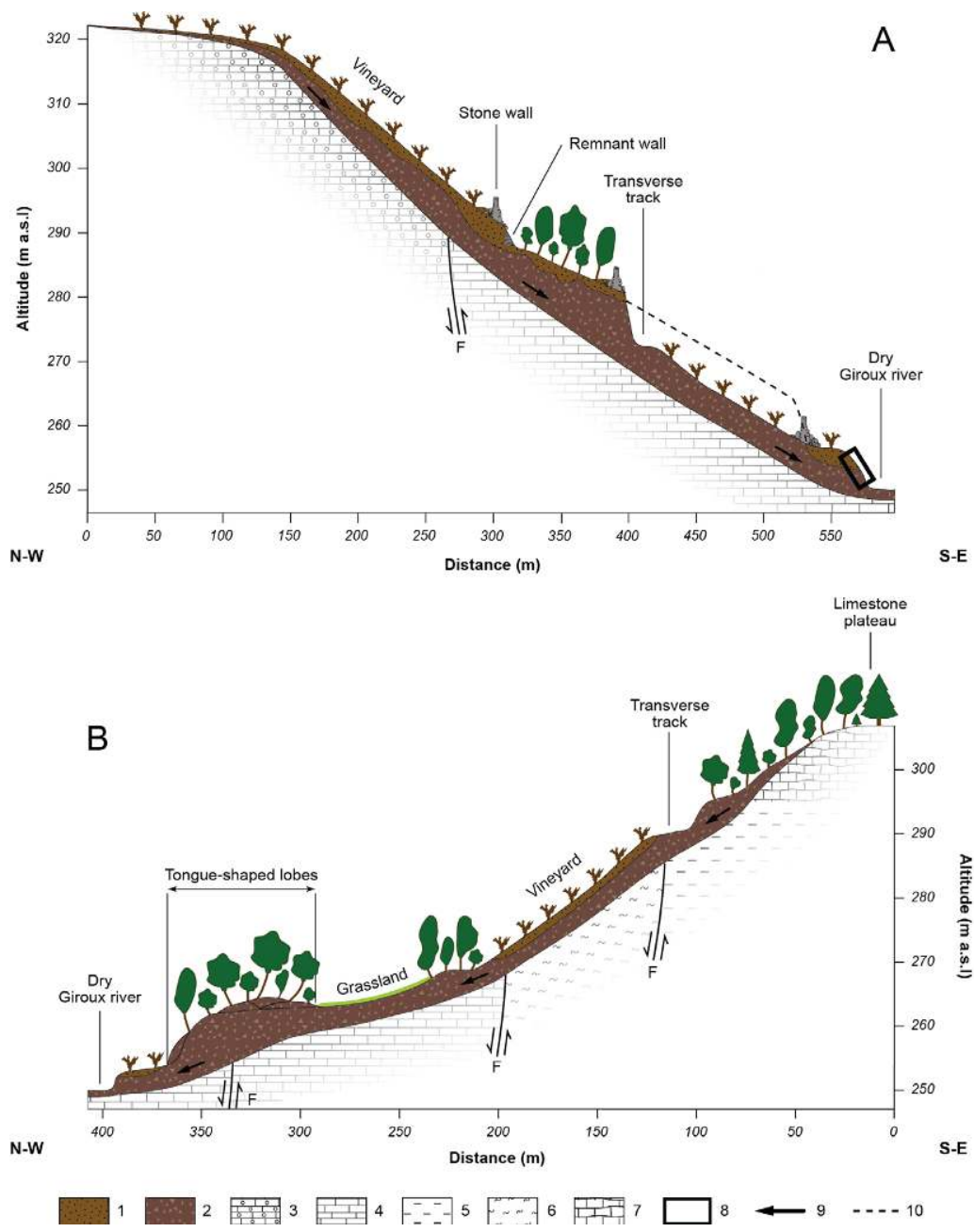

Fig. 10 - Hillslope profiles of the Pont Latin site.

Superficial deposits thickness is exaggerated five times compared to reality. A: Northern hillslope; B: Southern hillslope; 1. Fine matrix (clayey silts) with roughly bedding patterns; 2 . Matrix-supported diamictite with heterometric limestone clasts; 3 . "Chailles limestone" / oolithic limestone; 4. Red oolithic limestone; 5. Pale grey marl; 6. White marl; 7. Small bench limestone; 8 . Study trench; 9. Former solifluction dynamic; 10. Hypothetical palaeotopographic limit.

Fig. 10 - Topo-séquences des versants du site du Pont Latin.

L'épaisseur des dépôts superficiels est exagérée cinq fois par rapport à la réalité. A. Versant nord; $B$ Versant sud. 1. Matrice fine (limons argileux) avec une structure grossièrement litée ; 2. Diamicton à support matriciel riche en clastes calcaires hétérométriques ; 3 . Calcaires à chailles / calcaires oolithiques en plaques; 4. Calcaires oolithiques rouges ; 5. Marnes claires; 6. Marnes blanches ; 7. Calcaires en petits bancs; 8 . Coupe étudiée; 9. Ancienne dynamique de solifluxion; 10. Limite hypothétique de paléotopographie.

to a marly-limestone substratum (fig. 10A), characterized by a weak resistance to erosion, while the limestone substrate on the northern hillslope generates steeper escarpments (fig. 10B). On the upper part of the hillslopes, the substrate is near the surface. Superficial deposits are very fine and characterized by cryoturbation patterns. In the middle part of the northern hillslopes, sediment stores indicate colluvial deposits supplied by frost heave dismantling. In detail, the substrate is covered by an unsorted diamicton with multi-centimeter-sized angular clasts of limestone transported by high-energy geomorphic processes. This deposit is locally covered by a fine layer of roughly bedded and dark brown clayey silts, typical of low energy runoff processes. Its thickness is higher upstream stone walls that may have acted as a sieve, trapping sediments. The base of the hillslopes is covered by the same silty-clayey deposits.

Along the southern hillslope, sediment stores are not extensively visible (fig. 10B). Nevertheless, a quite large mass-movement is observed (approximately $350 \mathrm{~m}$ width), which front is localized at the contact between footslope and the valley bottom. Its facies is quite similar with the lower units of the Pont Latin trench (see sections 4.1.2. and 4.1.3.). In spite of deformations due to vineyard infrastructures, tongue-shaped lobes are evidenced at the front of the deposit, associated with a drunken forest (fig. 11). This type of forest is also observed in the source area corresponding to the upper part of the hillslope next to limestone plateau surface.

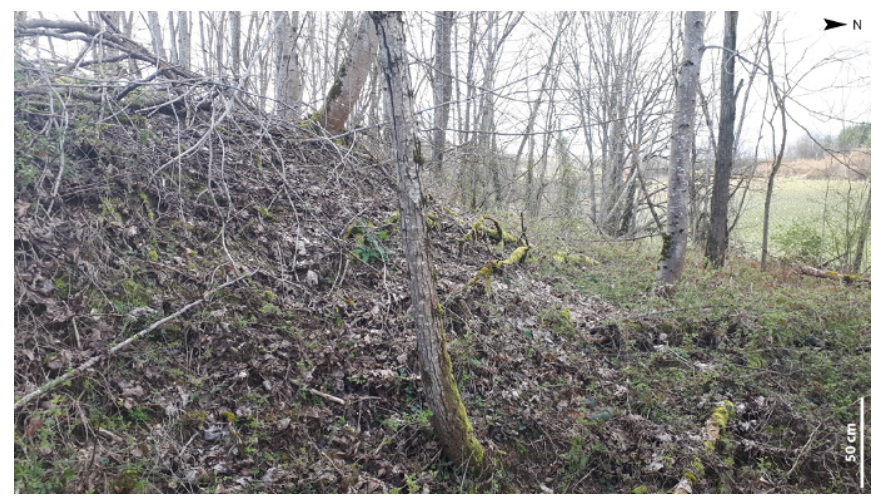

Fig. 11 - Front of a solifluction lobe and drunken forest observed on the southern hillslope of the Pont Latin site.

(photo credit: Chaize, 2020).

Fig. 11 - Front d'un lobe de solifluxion et forêt ivre identifiés sur le versant sud du site du Pont Latin (crédit photographique : Chaize, 2020).

(crédit photographique: Chaize, 2020).

\subsubsection{Valley bottom: profile B}

In the valley bottom and at the contact with the northern hillslope, Pont Latin trench is divided into five profiles, noted from A to E (fig. 12). Each profile is between 1 and $1.20 \mathrm{~m}$ high and may exhibit sediments that are provided by the northern hillslope to the valley 


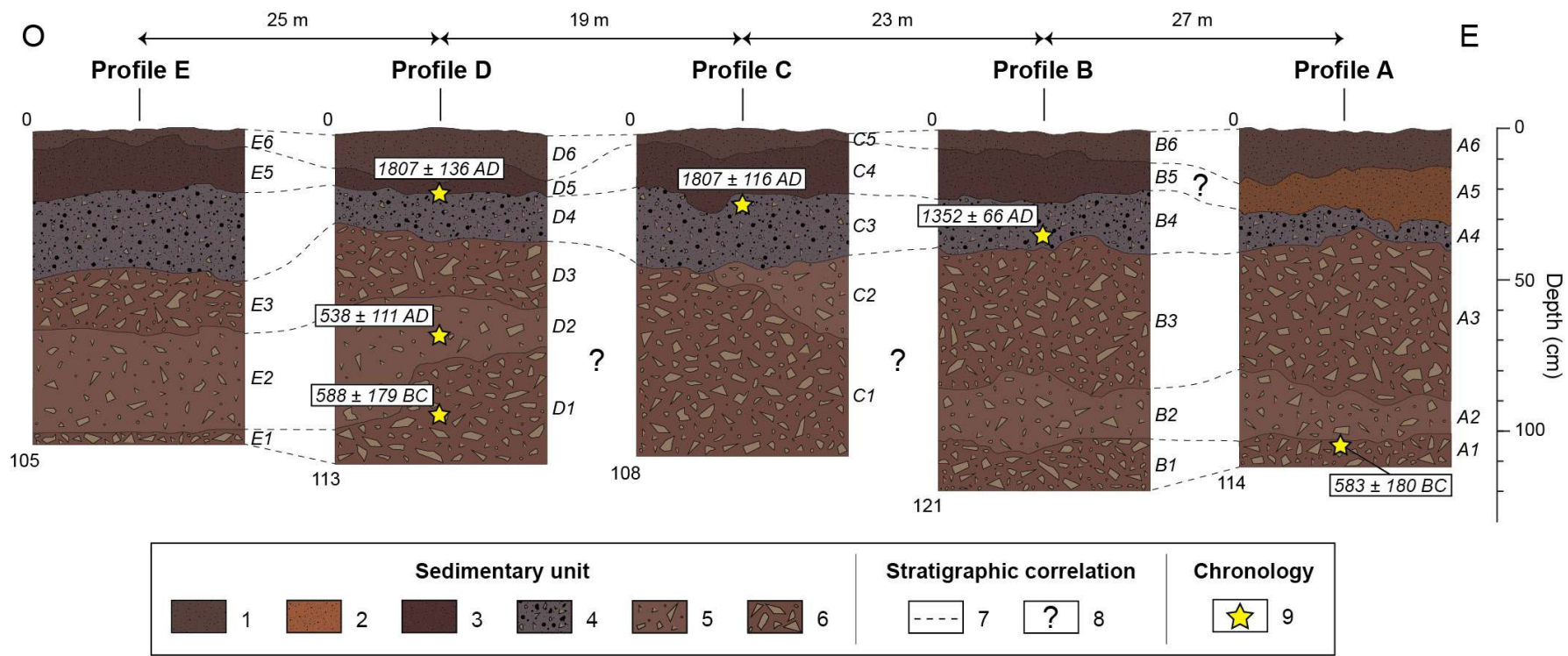

Fig. 12 - Stratigraphy and radiocarbon dating from profiles A to E of the Pont Latin trench.

1. Humus with roots and dark brown clayey silts; 2 . Roughly bedded yellowish brown clayey silts; 3 . Roughly bedded dusky red clayey silts; 4 . Roughly bedded dark grayish brown clayey silts with charcoal and small limestone clasts; 5 . Matrix-supported diamictite with heterometric angular limestone clasts; 6 . Matrix-supported diamictite with large angular limestone clasts; 7. Stratigraphic correlation; 8. Lack of stratigraphic correlation; 9. Radiocarbon dating (age cal. BC/AD).

Fig. 12 - Stratigraphie et datation par le radiocarbone des profils A à E de la coupe du Pont Latin.

1. Humus à racines et limons argileux brun foncé; 2. Limons argileux brun jaunâtre grossièrement lités; 3 . Limons argileux rouge brunâtre grossièrement lités; 4 . Limons argileux brun grisâtre grossièrement lités avec charbons et petits clastes calcaires; 5 . Diamicton à support matriciel riche en clastes calcaires anguleux hétérométriques; 6 . Diamicton à support matriciel riche en clastes calcaires anguleux pluricentimétriques; 7. Corrélation stratigraphique; 8. Absence de corrélation stratigraphique; 9. Datation au radiocarbone (âge cal. $B C / A D)$.

bottom. As the bedrock could not be reached, the sequence we observed only corresponds to the visible part of the deposits filling the valley bottom at this location.

The profile B overlooks the thalweg by $1.20 \mathrm{~m}$. It can be discriminated in six units vertically superimposed. As it is the thickest, it constitutes our reference profile for stratigraphic correlations and discussion. All profile units have been numbered by a facies code (tab. 2).
The first unit (from 107 to $120 \mathrm{~cm}$ deep) comprises multicentimeter-sized (sometimes decimeter-sized) angular clasts of limestone embedded in a dark red (2.5 YR 3/6, Munsell notation) silty-clayey matrix (B1, Fs.6). Above this chaotic basal layer, we find over approximately $20 \mathrm{~cm}$ (from 82 to $107 \mathrm{~cm}$ deep) a reddish brown (2.5 YR 4/4) silty-clayey matrix-supported diamictite made of angular clasts of limestone slightly smaller than the previous unit

Tab. 2 - Main sedimentary facies observed on the Pont Latin trench.

The facies with an asterisk (Fs.2) refers only to the profile A described below.

Tab. 2 - Principaux faciès sédimentaires identifiés sur la coupe du Pont Latin.

Le faciès avec un astérisque (Fs.2) se réfère uniquement au profil A décrit ci-après.

\begin{tabular}{|c|c|c|c|c|}
\hline Code & Texture & Structure & Color & Interpretation \\
\hline Fs.1 & silty-clayey & pedogenic features & $\begin{array}{l}\text { dark brown } \\
(10 \text { YR } 3 / 3)\end{array}$ & soil \\
\hline Fs. $2^{\star}$ & silty-clayey & $\begin{array}{l}\text { roughly bedding } \\
\text { patterns }\end{array}$ & $\begin{array}{l}\text { yellowish brown } \\
\quad(10 \text { YR } 5 / 8)\end{array}$ & $\begin{array}{l}\text { sieved deposit, } \\
\text { runoff process }\end{array}$ \\
\hline Fs.3 & silty-clayey & $\begin{array}{l}\text { roughly bedding } \\
\text { patterns }\end{array}$ & $\begin{array}{l}\text { dusky red } \\
(10 \mathrm{R} 3 / 4)\end{array}$ & $\begin{array}{l}\text { sieved deposit, } \\
\text { runoff process }\end{array}$ \\
\hline Fs.4 & $\begin{array}{l}\text { silty-clayed matrix with some } \\
\text { sub-centimetric shattered clasts of limestone }\end{array}$ & $\begin{array}{l}\text { roughly bedding } \\
\text { patterns }\end{array}$ & $\begin{array}{l}\text { dark grayish brown } \\
\quad(10 \mathrm{YR} 4 / 2)\end{array}$ & $\begin{array}{l}\text { sieved deposit, } \\
\text { runoff process }\end{array}$ \\
\hline Fs. 5 & $\begin{array}{c}\text { unsorted deposit made of angular } \\
\text { limestone clasts (larger clasts of } 5 \text { to } 7 \mathrm{~cm} \\
\text { for the main axes) within a silty-clayey matrix }\end{array}$ & $\begin{array}{c}\text { massive } \\
\text { (chaotic appearence) }\end{array}$ & $\begin{array}{l}\text { reddish brown } \\
(2.5 \text { YR } 4 / 4)\end{array}$ & $\begin{array}{l}\text { solifluction } \\
\text { hyperconcentrate flows }\end{array}$ \\
\hline Fs.6 & $\begin{array}{l}\text { unsorted deposit made of angular } \\
\text { limestone clasts (larger clasts of } 10 \text { to } 12 \mathrm{~cm} \\
\text { for the main axes) within a silty-clayey matrix }\end{array}$ & $\begin{array}{c}\text { massive } \\
\text { (chaotic appearence) }\end{array}$ & $\begin{array}{c}\text { dark red } \\
(2.5 \mathrm{YR} 3 / 6)\end{array}$ & $\begin{array}{l}\text { solifluction } \\
\text { hyperconcentrate flows }\end{array}$ \\
\hline
\end{tabular}


(B2, Fs.5). Upward, an unsorted diamicton level is similar to the basal unit but much more vertically expanded (from 40 to $82 \mathrm{~cm}$ deep). This consists of abundant large clasts of angular limestone embedded in a dark red (2.5 YR 3/6) silty-clayey matrix (B3, Fs.6). These first three units lacked any readily discernible sedimentary structure and their upper contact is diffuse and undulating. They are interpreted as colluvial deposits (Bertran, 2004) even if it remains difficult to discriminate whether it corresponds to solifluction processes or hyperconcentrated runoff. In both cases, high energy processes are involved and may have reworked periglacial deposits previously stored along hillslope and on plateau.

The upper part of this profile indicates a change in sediments grain size with the superposition of three roughly bedded units quite fine, up until the summit. These latter are rich in organic remnants which include numerous charcoal fragments and rootlets, as well as faunal remains such as mollusc shells. From 22 to $40 \mathrm{~cm}$ deep, we find a dark grayish brown (10 YR 4/2) matrix (B4, Fs.4). Sub-centimetric angular and subangular clasts of limestone are found occasionally mixed with the silt- and clay-sized sediments. The abundant presence of charcoal, ashes and soot that stain the sediment explains its coloring. The upper contact of this unit is sharp and delineated by dusky red (10 R 3/4) clayey silts devoid of coarse material, which is continuous for $15 \mathrm{~cm}$ high (B5, Fs.3). The transition to the summit unit is diffuse over the remaining $8 \mathrm{~cm}$. This upper unit is predominantly dark brown (10 YR 3/3) clayey silts (B6, Fs.1). Underlying a fine surface vegetation mat, it is the support of current pedogenesis. Roots from the surface vegetation penetrate throughout this unit. Among these last three units, B4 and B5 are interpreted as sieved runoff deposits.

\subsubsection{Valley bottom: profiles $A, C, D$ and $E$}

Four other profiles surveyed on the Pont Latin trench complement data acquired on the profile $B$. In the same way as the reference profile, profiles A, C, D and E show two phases of vertical accretion: (i) diamictite levels up to approximately $40 \mathrm{~cm}$ below the surface, and (ii) a upper part characterized by fine and roughly bedded levels more or less organic.

In detail, the dusky red silty-clayey unit (B5, Fs.3) is replaced on profile A by a yellowish brown (10 YR 5/8) silty-clayey lens from 12 to $28 \mathrm{~cm}$ deep (A5, Fs.2). A pedogenesis phase or the post-depositional processes of mineral accumulation are probably the reason for the facies coloring.

Profile $\mathrm{C}$ is the only one with a sedimentary accumulation showing a strictly decreasing grain size organization. It corresponds to the transition from shattered large limestone clasts levels to increasingly fine levels that go richer in organic matter. This profile is locally gullied by a lens comprising a silty-clayey matrix-supported diamictite with heterometric angular clasts of limestone (C4, Fs.5). Its thickness laterally decreases. It is approximately up to $25 \mathrm{~cm}$ in thickness on the east side but on the west side, it only reaches $10 \mathrm{~cm}$. Above it, we find the unit associated with dark grayish brown clayey silts (C3, Fs.4) described in all profiles. It vertically extends over about $20 \mathrm{~cm}$. The absence in profile $\mathrm{C}$ of a second level of unsorted diamicton with multi-centimeter-sized angular clasts of limestone (similar to B3) is another element of variation from the reference profile.

Finally, profiles D and E do not reveal any significant difference from profile B. Indeed, units D1 to D6 and C1 to C6 correspond to units $\mathrm{B} 1$ to $\mathrm{B} 6$, whose facies are similar. However, units thickness variations constitute a significant discrepancy. Also, profile D basal unit (D1, Fs.6) is truncated on its upstream part by the overlying unit (D2, Fs.5). It thus varies from 14 to $41 \mathrm{~cm}$ in thickness.

\subsection{Soil charcoal assemblages}

More than 170 charcoal were identified in the five profiles (tab. 3). These data have been divided in three pedoanthracological phases (Z1a, Z1b and Z2) which correspond to similar taxonomic trends between profiles (fig. 13A-B). Dogwood (Cornus sanguinea) and spindle (Euonymus europaeus), which are not frequent and difficult to ecologically discriminate, are not mentioned in the following development.

Starting to the lower part of profiles, diagrams reveal a first pedoanthracological phase (Z1a) with only 25 fragments (fig. 13A). The assemblage consists of five tree taxa. Oak (Quercus sp.) is the main species with $60 \%$ of the determined remains (fig. 13B). In this region, this species probably corresponds to pubescent oak (Quercus pubescens), but sessile oak (Quercus petraea) presence is also possible. These oak charcoal do not fit with the hydromorphic conditions of the studied valley bottom. Consequently, they are brought in from the peripheral hillslopes. Hornbeam (Carpinus betulus) and beech (Fagus sylvatica) can be associated with a deciduous oak forest facies, both of which are sparse ( $8 \%$ and $16 \%$ respectively). Beech is a mountain climate taxon which brings a cooler/wetter tone to this forest formation. In this first phase, sediments also yielded some hazel fragments (Corylus avellana) and a fragment of Prunus. These heliophilous trees are indicators of open areas or forest edges.

The second pedoanthracological phase (Z1b) is richer (47 fragments studied) and more diversified (seven tree and shrub taxa). Taxa typical of a riparian forest are identified. It encompasses willow (Salix sp.) or poplar (Populus sp.) which represent $40 \%$ of the total charcoal in this phase. Willow and poplar can hardly be discriminated from each other from anatomical criteria and are grouped under the taxon Populus sp./Salix sp. Deciduous oak is also identified with $32 \%$ of the determined fragments. The other species of deciduous oak grove become scarce: beech appears only once and hornbeam is no longer identified. Furthermore, the first occurrences of vine (Vitis sp.) appear in pedoanthracological sampling. Some rare fragments of Scots pine (Pinus sylvestris) were also found. The first two phases (Z1a and Z1b) are placed on coarse sedimentation units (diamicton). It could explain why embedded charcoal in these deposits are often small (sub-millimetric).

Finally, the third pedoanthracological phase (Z2) is characterised by a high concentration of charcoal and a considerable spectrum depletion in favor of vine. Beyond $40 \mathrm{~cm}$ deep, assemblage proved to be almost monospecific: $84 \%$ of the 104 charcoal samples identified are related to Vitis genus. Even if they represent only a small proportion of the pedoanthracocenosis, other species are integrated into the reconstituted woody vegetation in this last part. Among these, Scots pine is discrete (9\%) but present in three profiles, while riparian vegetation (Salix sp./Populus sp.) only represents $5 \%$ of the assemblage. This last phase is stratigraphically positioned to the thinnest deposits. 


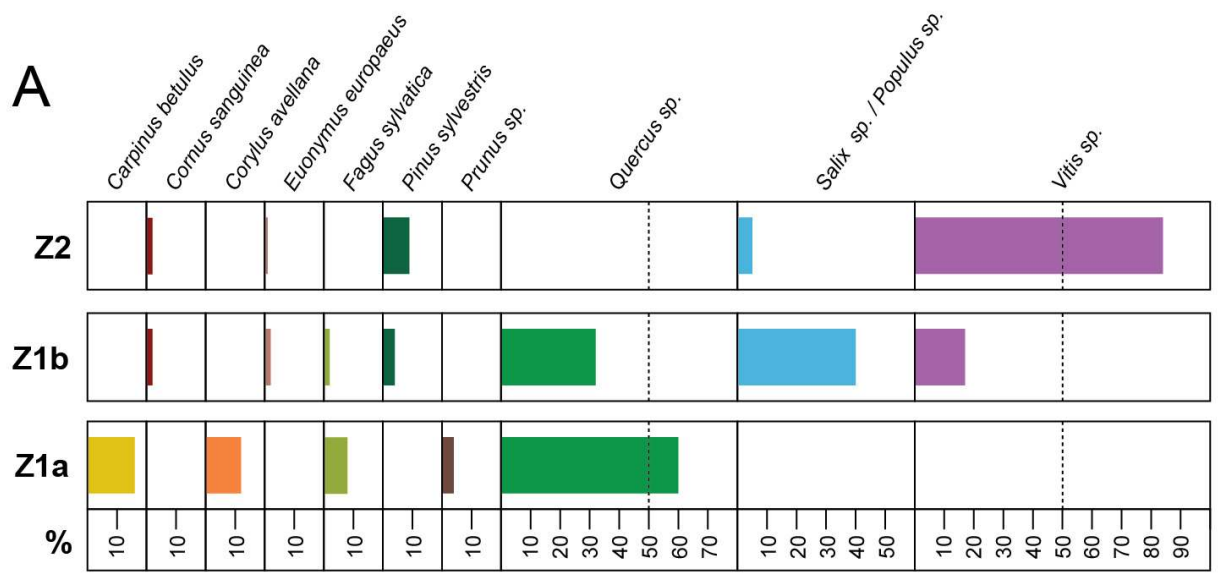

B

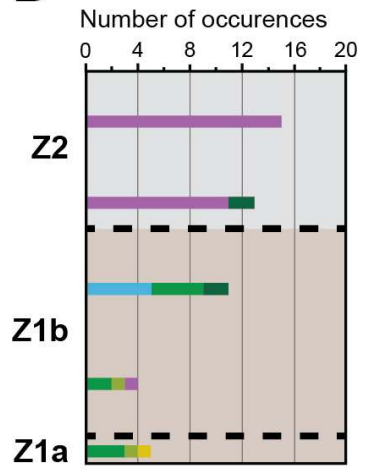

Profile E

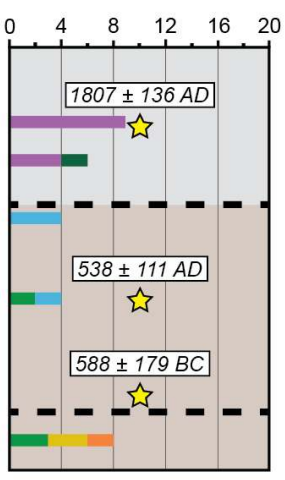

Profile D

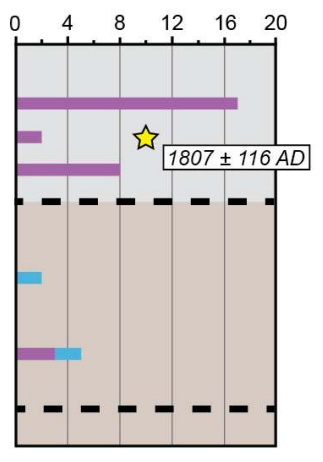

Profile C

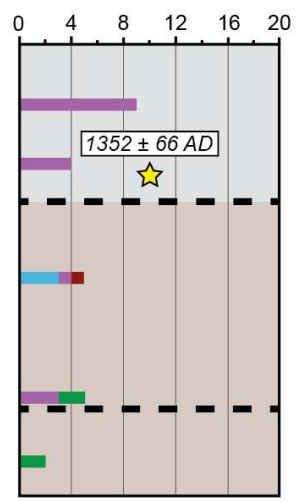

Profile B

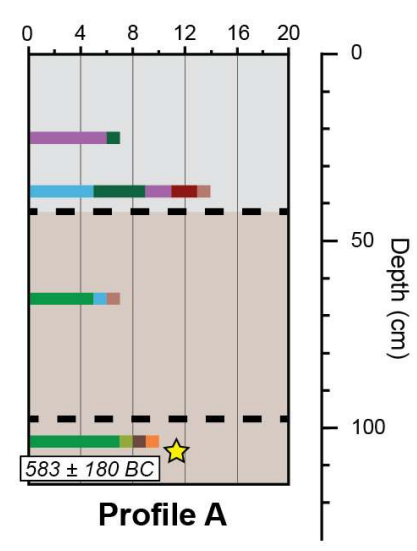

Pedoanthrocological spectrum

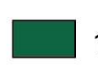

$\square 2$

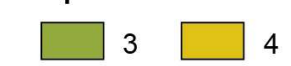

4
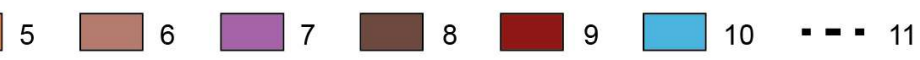

\section{Simplified sedimentary unit}

12

13

\section{Chronology}

\section{is 14}

Fig. 13 - Semi-quantitative results of pedoanthracological diagrams of the Pont Latin trench.

A. Relative frequency distribution per pedoanthracological phase; B. Absolute frequency distribution per profile. 1. Scots pine (Pinus sylvestris); 2. Oak (Quercus sp.); 3. Beech (Fagus sylvatica); 4. Hornbeam (Carpinus betulus); 5 . Hazel (Corylus avellana); 6. Spindle (Euonymus europaeus); 7. Vine (Vitis sp.); 8 . Prunus (Prunus sp.); 9. Dogwood (Cornus sanguinea); 10. Willow / Poplar (Salix sp./Populus sp.); 11. Discontinuity in pedoanthracological signal; 12. Fine matrix (clayey silts) with roughly bedding patterns; 13 . Matrixsupported diamictite with shattered limestone clasts of various size; 14. Radiocarbon dating (age cal. BC/AD).

\section{Fig. 13 - Résultats semi-quantitatifs des analyses pédoanthracologiques de la coupe du Pont Latin.}

A. Répartition des fréquences relatives par phase pédoanthracologique; B. Répartition des fréquences absolues par profil. 1. Pin sylvestre (Pinus sylvestris); 2. Chêne (Quercus sp.); 3 . Hêtre commun (Fagus sylvatica); 4. Charme commun (Carpinus betulus); 5. Noisetier commun (Corylus avellana); 6. Fusain d'Europe (Euonymus europaeus); 7. Vigne (Vitis sp.); 8. Prunus (Prunus sp.); 9. Cornouiller sanguin (Cornus sanguinea); 10. Saule/Peuplier (Salix sp./Populus sp.); 11. Discontinuité dans le signal pédoanthracologique; 12. Matrice fine (limons argileux) avec une structure grossièrement litée; 13. Diamicton à support matriciel riche en clastes calcaires anguleux de taille variée; 14 . Datation au radiocarbone (âge cal. BC/AD).

\subsection{Chronology}

Radiocarbon dating provides a chronological framework of approximately 2,700 years and a terminus post quem for the genesis of the geomorphological dynamics identified. Indeed, geomorphic processes reworked charcoal that has been previously burnt. The ages of three samples were rejected because they are very close to (PLPE2) or beyond (PLPB2 and PLPB3) the limits of radiocarbon scope (tab. 4). The dated elements certainly correspond to old charcoal resulting from natural fires, or to inorganic charcoal (lignite) whose presence is abundant in the sedimentary records studied.

Samples location is described from their belonging to sedimentological units and pedoanthracological phases in the studied profiles. Three dates are acquired throughout profile D, providing the best chronological constraint of the sequence. At 
Tab. 3 - Charcoal fragment count per taxa and per profile.

Tab. 3 - Nombre de fragments de charbon par taxon et par profil.

\begin{tabular}{|c|c|c|c|c|c|c|c|c|c|c|c|c|}
\hline & & $\begin{array}{c}\text { Carpinus } \\
\text { betulus }\end{array}$ & $\begin{array}{c}\text { Cormus } \\
\text { sanguinea }\end{array}$ & $\begin{array}{c}\text { Corylus } \\
\text { avellana }\end{array}$ & $\begin{array}{l}\text { Euonymus } \\
\text { europaetus }\end{array}$ & $\begin{array}{c}\text { Fagus } \\
\text { sylvatica }\end{array}$ & $\begin{array}{c}\text { Pinus } \\
\text { sylvestris }\end{array}$ & $\begin{array}{c}\text { Prunus } \\
\text { sp. }\end{array}$ & $\begin{array}{c}\text { Quercus } \\
\text { sp. }\end{array}$ & $\begin{array}{l}\text { Vitis } \\
\text { sp. }\end{array}$ & $\begin{array}{c}\text { Salix sp./ } \\
\text { Populus sp. }\end{array}$ & Total \\
\hline \multirow{6}{*}{ Profil A } & $\mathrm{A} 6$ & \multicolumn{11}{|c|}{ not analyzed (too recent) } \\
\hline & A5 & 0 & 0 & 0 & 0 & 0 & 1 & 0 & 0 & 6 & 0 & 7 \\
\hline & A4 & 0 & 2 & 0 & 1 & 0 & 4 & 0 & 0 & 2 & 5 & 14 \\
\hline & A3 & 0 & 0 & 0 & 1 & 0 & 0 & 0 & 5 & 0 & 1 & 7 \\
\hline & $\mathrm{A} 2$ & 0 & 0 & 0 & 0 & 0 & 0 & 0 & 0 & 0 & 0 & 0 \\
\hline & $\mathrm{Al}$ & 0 & 0 & 1 & 0 & 1 & 0 & 1 & 7 & 0 & 0 & 10 \\
\hline \multirow{6}{*}{ Profil B } & B6 & \multicolumn{11}{|c|}{ not analyzed (too recent) } \\
\hline & B5 & 0 & 0 & 0 & 0 & 0 & 0 & 0 & 0 & 9 & 0 & 9 \\
\hline & B4 & 0 & 0 & 0 & 0 & 0 & 0 & 0 & 0 & 4 & 0 & 4 \\
\hline & B3 & 0 & 1 & 0 & 0 & 0 & 0 & 0 & 0 & 1 & 3 & 5 \\
\hline & $\mathrm{B} 2$ & 0 & 0 & 0 & 0 & 0 & 0 & 0 & 2 & 3 & 0 & 5 \\
\hline & $\mathrm{B} 1$ & 0 & 0 & 0 & 0 & 0 & 0 & 0 & 2 & 0 & 0 & 2 \\
\hline \multirow{5}{*}{ Profil C } & $\mathrm{C} 5$ & \multicolumn{11}{|c|}{ not analyzed (too recent) } \\
\hline & $\mathrm{C} 4$ & 0 & 0 & 0 & 0 & 0 & 0 & 0 & 0 & 17 & 0 & 17 \\
\hline & $\mathrm{C} 3$ & 0 & 0 & 0 & 0 & 0 & 0 & 0 & 0 & 10 & 0 & 10 \\
\hline & $\mathrm{C} 2$ & 0 & 0 & 0 & 0 & 0 & 0 & 0 & 0 & 0 & 2 & 2 \\
\hline & $\mathrm{Cl}$ & 0 & 0 & 0 & 0 & 0 & 0 & 0 & 0 & 3 & 2 & 5 \\
\hline \multirow{6}{*}{ Profil D } & D6 & \multicolumn{11}{|c|}{ not analyzed (too recent) } \\
\hline & D5 & 0 & 0 & 0 & 0 & 0 & 0 & 0 & 0 & 9 & 0 & 9 \\
\hline & $\mathrm{D} 4$ & 0 & 0 & 0 & 0 & 0 & 2 & 0 & 0 & 4 & 0 & 6 \\
\hline & D3 & 0 & 0 & 0 & 0 & 0 & 0 & 0 & 0 & 0 & 4 & 4 \\
\hline & $\mathrm{D} 2$ & 0 & 0 & 0 & 0 & 0 & 0 & 0 & 2 & 0 & 2 & 4 \\
\hline & D1 & 3 & 0 & 2 & 0 & 0 & 0 & 0 & 3 & 0 & 0 & 8 \\
\hline \multirow{6}{*}{ Profil E } & E5 & \multicolumn{11}{|c|}{ not analyzed (too recent) } \\
\hline & E6 & 0 & 0 & 0 & 0 & 0 & 0 & 0 & 0 & 15 & 0 & 15 \\
\hline & $\mathrm{E} 4$ & 0 & 0 & 0 & 0 & 2 & 0 & 0 & 11 & 0 & 0 & 13 \\
\hline & E3 & 0 & 0 & 0 & 0 & 0 & 2 & 0 & 4 & 0 & 5 & 11 \\
\hline & E2 & 0 & 0 & 0 & 0 & 1 & 0 & 0 & 2 & 1 & 0 & 4 \\
\hline & El & 1 & 0 & 0 & 0 & 1 & 0 & 0 & 3 & 0 & 0 & 5 \\
\hline Total & & 4 & 3 & 3 & 2 & 5 & 9 & 1 & 41 & 84 & 24 & 176 \\
\hline
\end{tabular}

Tab. 4 - Radiocarbon dating obtained on the Pont Latin trench.

Tab. 4 - Datations par le radiocarbone obtenues sur la coupe du Pont Latin.

\begin{tabular}{|c|c|c|c|c|c|}
\hline Sample & $\begin{array}{l}\text { Depth } \\
(\mathrm{cm})\end{array}$ & $\begin{array}{l}\text { Laboratory } \\
\text { code }\end{array}$ & Material & $\begin{array}{c}\text { Measured age } \\
(B P)\end{array}$ & $\begin{array}{c}\text { Calibrated age } \\
\text { (cal. } B C / A D-2 \sigma)\end{array}$ \\
\hline PLPA1 & 104-108 & Poz-116719 & $\begin{array}{c}\text { Charcoal } \\
\text { (Quercus sp.) }\end{array}$ & $2435 \pm 30$ & $588 \pm 179 \mathrm{BC}$ \\
\hline PLPB4 & $35-40$ & Poz-116720 & $\begin{array}{l}\text { Charcoal } \\
\text { (Vitis sp.) }\end{array}$ & $605 \pm 30$ & $1352 \pm 66 \mathrm{AD}$ \\
\hline PLPB3 $^{*}$ & $59-64$ & Poz-116721 & Charcoal & $>52000$ & - \\
\hline PLPB2* & $95-100$ & Poz-116722 & Charcoal & $>50000$ & - \\
\hline PLPC3 & $20-25$ & Poz-116723 & $\begin{array}{l}\text { Charcoal } \\
\text { (Vitis sp.) }\end{array}$ & $112.47 \pm 0.32$ & $1807 \pm 116 \mathrm{AD}$ \\
\hline PLPD5 & $19-22$ & Poz-116725 & $\begin{array}{c}\text { Charcoal } \\
\text { (Salix sp./ Populus sp.) }\end{array}$ & $135 \pm 30$ & $1807 \pm 136 \mathrm{AD}$ \\
\hline PLPD2 & 67 & Poz-116725 & Charcoal & $1495 \pm 30$ & $538 \pm 111 \mathrm{AD}$ \\
\hline PLPD1 & 96.5 & UBA-39224 & Charcoal & $2456 \pm 27$ & $588 \pm 179 \mathrm{BC}$ \\
\hline PLPE2* & 81.5 & UBA-39222 & Charcoal & $>49728$ & - \\
\hline
\end{tabular}

The samples with an asterisk were rejected because their ages are very close to or went over the radiocarbon dating capacity. Unidentified charcoal corresponds to a preliminary study preceding the launch of the current research project.

Les échantillons avec un astérisque ont été écartés parce que leurs âges sont très proches ou au-delà de la portée pratique du radiocarbone. Les charbons non identifiés correspondent à une étude préliminaire précédant le lancement du projet de recherche actuel. 
the bottom, the diamicton unit with dark red silty-clayey matrix (D1) yields an age of $588 \pm 179$ cal. BC consistent with the First Iron Age. This date performs on an unspecified charcoal but which belongs to the pedoanthracological phase dominated by Quercus taxa (Z1a). It may therefore be tens or hundreds of years older than the matrix from which it is recovered. Another charcoal, sampled in the middle part of the overlying coarse unit (D2, Z1b), refers to the transition between the Late Antiquity and the Early Middle Ages $(538 \pm 111 \mathrm{cal}$. AD). The interface between the dark grayish brown silty-clayey unit (D4, Z2) and the dusky red silty-clayey unit (D5, Z2) indicates an age of $1807 \pm 136 \mathrm{cal}$. AD and can be attributed to the Modern and Contemporary periods.

Only one date has been acquired from profile A. It comes from the top of the diamicton unit with a red dark silty-clayey matrix (A1) and belongs to the lower pedoanthracological phase (Z1a). It gives an age of $583 \pm 180 \mathrm{cal}$. BC, corresponding to the First Iron Age. Derived from an oak charcoal, it may also be subject to the "old wood effect".

On profile $\mathrm{B}$, an age $(1352 \pm 66 \mathrm{cal}$. AD) acquired from the base of the dark grayish brown clayey silts (B4, Z2) suggests a sedimentary deposit latter than the Central Middle Ages. On profile $\mathrm{C}$, the top of this same unit $(\mathrm{C} 3, \mathrm{Z} 2)$ reveals an age $(1807 \pm 116 \mathrm{cal}$. AD) related to the Modern and Contemporary periods.

Most of the dates we obtained are located on radiocarbon plateaus. This leads to inaccuracies, generally greater than 100 years cal. BC/AD. Extended general chronological frame can nevertheless be discussed.

\section{Discussion}

Mercurey geomorphic evolution is characterized by two major changes in terms of sedimentary signal, the hinge of which remains to be precisely dated (fig. 14A-B). The chronological boundaries of the two phases are given in the broadest possible way. We draw here some hypotheses to interpret the variability of such signal thanks to pedoanthracological data and regional correlations.

\subsection{Phase 1: High-energy geomorphic processes in an opening forest landscape.}

This first phase covers a very broad period at least from $800 \mathrm{cal}$. $\mathrm{BC}$ to $1400 \mathrm{cal}$. AD. It includes the basal diamicton unit (B1) which yields an age related to the First Iron Age on profiles A and D. This unit seems to reflect the valley bottom filling by materials supplied from frost heave screes (from limestone ledges sources) accumulated during Pleistocene and transported by colluvial processes at least from 800 cal. BC (fig. 14A). During Pleistocene, seasonal freezing and thawing in the Burgundian periglacial environments caused intense disintegration of the limestone ledges (Ciry, 1951, 1959; Rat, 1953; Campy, 2017), providing sediments to the stores located along hillslopes. During the Holocene warmer periods that followed, such sediment stores (e.g., screes) were reworked through colluvial processes requiring large amount of water and revealing slope instability. The occurrence of a mass-movement on the southern hillslope suggests the hypothesis of solifluction processes along the northern hillslope. As the study trench base does not reach the bedrock, previous sedimentary dynamics (i.e., from the Late Pleistocene to $800 \mathrm{cal}$. BC) remain unknown. Then, the grain size of unit $\mathrm{B} 2$ indicates that these high-energy geomorphic processes occurred after the transition between the Late Antiquity and the Early Middle Ages. Indeed, stratigraphically correlated to unit B2, unit D2 provides a historical anchorage at $538 \pm 111 \mathrm{cal}$. AD. Finally, this phase of coarse sedimentation includes unit B3 and interrupts before the Central Middle Ages (1352 \pm 66 cal. AD) with dark grayish brown clayey silts deposition (B4). A time gap during the Gallo-Roman period is noticed, probably due to a river incision or too high radiocarbon ages related to the "old wood effect". Considering the micro-regional scope of this sedimentary hiatus (Garcia et al., 2008), the first hypothesis is favoured. Additional sedimentary records within the Giroux catchment are currently being studied to resolve this issue.

If we consider landscape evolution, diamicton units intersect two woody formations. The first one (Z1a) is a deciduous forest composed of oak (Quercus sp.), hazel (Corylus avellana), beech (Fagus sylvatica) and hornbeam (Carpinus betulus). It certainly grows on the peripheral hillslopes of the Pont Latin trench. Discreetly present in this first phase, beech demonstrates the forest maturity (Robin et al., 2013) and the climate humidity (Delhon, 2005). These climatic conditions contributed to high-energy geomorphic processes. It could coincide with the cooler and wetter period of the First Iron Age (Haas et al., 1998; Magny, 2004). The over-representation of oak taxa in charcoal assemblages during this protohistoric period is consistent with the results of regional palaeoenvironmental analyses (Jouffroy-Bapicot, 2010; Laine et al., 2010; Argant et al., 2011). The identification of a heliophilous taxon such as hazel suggests a sparse forest (Bégeot, 2013). The presence of an open forest is in accordance with the hillslope dynamics and may have predisposed such processes. The pedoanthracological signal also allows us to identify the emergence of anthropogenic land uses, especially landscape opening, probably for agro-pastoral needs as suggested by archaeological data (see section 2.2.).

The second formation (Z1b) is representative of a riparian forest and suggests an ecological maintenance or exploitation of the alluvial lands near the study site (Delhon, 2005). According to the age of $538 \pm 111 \mathrm{cal}$. AD, such practices occurred during the transition between the Late Antiquity and the Early Middle Ages. Concerning vine occurrences within this first detritism phase, it is not possible to distinguish between its wild and domestic forms. Wild vine (Vitis sylvestris) could be suggested by the abundance of riparian taxa (Salix sp./Populus sp.) as the riparian forest is an environment in which wild vine naturally grows (Gauthier, 2000). However, domestic vine (Vitis vinifera) cannot be dismissed due to the chronological limits of the first phase. They include the GalloRoman period where vine was introduced in Burgundy (Garcia et al., 2010).

\subsection{Phase 2: Controlled geomorphic processes in a wine- growing landscape}

The coarse grain deposition phase is replaced by an accumulation of fine and roughly bedded sediments after $1400 \mathrm{cal}$. AD. All profiles of the Pont Latin trench and sediment stores along hillslopes record 
A

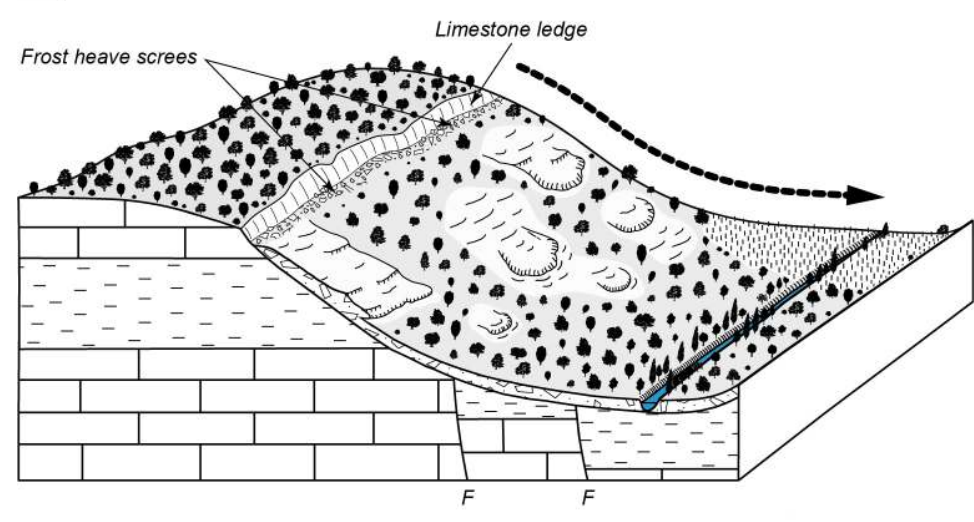

B

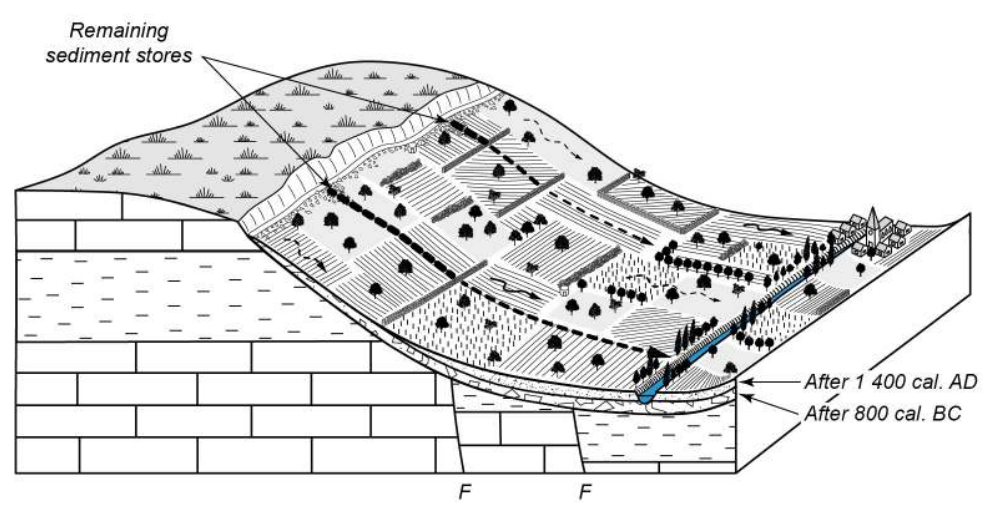

Surfacial deposits

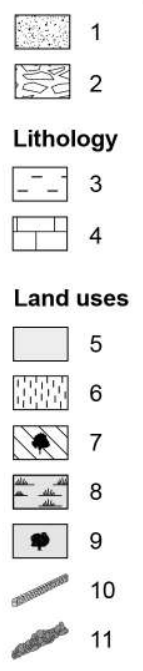

Geomorphological processes

$\overrightarrow{-m} \mid 12$

$\stackrel{-\infty}{-\infty} 12$

? 13

W(1) 14

己) 15
Fig. 14 - Sedimentary and landscape dynamics of the Pont Latin site since the First Iron Age.

A. At least from 800 cal. BC; B. After 1400 cal. BC. 1. Roughly bedded clayey silts; 2. Unsorted deposit made of angular limestone clasts (many centimeters) within a silty-clayey matrix; 3. Marl and limestone marl; 4. Lithographic limestone; 5. Grassland; 6. Cereal crop; 7. Vineyard and orchard; 8. Heathland; 9. Deciduous oak grove; 10 . Dry-stone wall; 11. Unstructured pile of stones ("meurger"); 12. Grain size in sedimentary fluxes; 13. Runoff plot; 14. High amplitude lobe (superficial landslide); 15. Low amplitude lobe (creep/plastic deformation).

Fig. 14 - Dynamiques sédimentaires et paysagères du site du Pont Latin depuis le premier âge du Fer.

A. Au moins à partir de $800 \mathrm{cal}$. BC ; B. Après $1400 \mathrm{cal}$. AD. 1. Limons argileux grossièrement lités ; 2 . Dépôt massif de clastes anguleux pluricentimétriques dans une matrice limono-argileuse ; 3. Marnes et marnes-calcaires ; 4 . Calcaire lithographique ; 5 . Surface enherbée ; 6 . Culture céréalière ; 7. Complantage de vignes et de vergers ; 8 . Lande steppique ; 9. Chênaie caducifoliée; 10 . Mur de pierres sèches ; 11. Tas de pierres d'épierrement (" meurger "); 12. Taille des grains dans les flux sédimentaires; 13. Ruissellement parcellaire ; 14. Lobe de forte amplitude (glissement superficiel) ; 15. Lobe d'amplitude limitée (reptation/déformation plastique). this change in sediments grain size. Sediment cascade is only able to transport fine clastic (B4) or clayey silts (B5), while Little Ice Age hydroclimatic deterioration (1350-1850 cal. AD) (Magny et al., 1995; Mann et al., 2008) was probably stimulating the geomorphic processes. In that case, two hypotheses arise: (i) sediment sources are exhausted or (ii) geomorphic processes are disorganized from source areas to valley bottom, so that sediment transportation is hindered.

The significant evolution in sediments grain size is simultaneous with a noticeable change in the pedoanthracological signal, and thus in terms of land uses. The charcoal assemblages of the two upper units record a large number of vine fragments (Z2). This monotonous spectrum reflects a special attention from local populations to this species. Through pedoanthracological analysis we cannot differentiate wild vine from domestic vine. However, the sudden abundance of Vitissp. and the rarefaction of other riparian species (Salix sp./Populus $s p$.) suggest local development of domestic vine. The observation of vine from $1400 \mathrm{cal}$. AD is chronologically close to trends registered in other parts of the Burgundy vineyard. They seem to coincide with the spread of vine in the Burgundian landscape from the feudal period (900-1100 cal. AD) (Garcia et al., 2008). After the Gallo-Roman period, when vine cultivation seems to be limited to the plain (Garcia et al., 2010; Garcia et al., 2011; Garcia, 2012; Garcia et al., 2017b), the vineyard grows on the hillslopes under the influence of religious institutions settled near the Côte de Bourgogne (e.g., Cistercians and Benedictines). Because of their agronomical knowledge, they start growing vine on hillslopes to enhance the quality of their wine production. Local urban aristocracy is also associated with the spatial diffusion of the vine (Dion, 2010) as human settlements and demand for agricultural products increase (Larsen et al., 2016). The medieval landscape then consists of ever more numerous vine plots, interspersed with pastures, various cultures and fruit trees arranged either along hillslopes and ditches or between vine rows (fig. 14B).

As the vineyard gradually spreads across the landscape and vines are cultivated on hillslopes, networks of dry-stone walls and unstructured piles of stones (called "meurgers") are built between plots starting from the $9^{\text {th }}$ century (Garcia, 2011) even possibly before (Haasé, 1977; Harfouche, 2017). In Mercurey vineyard, it is still difficult to date such man-made infrastructures. We however note that they are always built on coarse colluvial deposits and that they are intermingled with finer and roughly bedded deposits of the second stage. More than just delimiting vineyard ownerships, these stone structures increase the roughness of the hillslopes, thus causing soil particles to be retained (Garcia et al., 2018; Quiquerez et al., 2018; Labbé and Garcia, 2019). When the axes of these infrastructures are perpendicular to the highest slope gradient, they impede sedimentary flows and disorganizes the sediment cascade along hillslopes (Jorda and Provansal, 1990). Dry-stone walls and unstructured piles of stones correspond to local base-level favoring sediments trapping. In detail, they are permeable and act as a sieve: water and fine sediments pass through while coarse sediments are trapped. Thus, frost heave screes that have been transported from the base of the limestone ledges are stored upstream of the walls and no longer manage to reach the valley 
bottom. Consequently, these anthropogenic infrastructures may explain the facies of the deposits observed on the Pont Latin trench after $1400 \mathrm{cal}$. AD. We thus prioritize the hypothesis that geomorphic processes acting along sediment cascade are partly decoupled from biophysical and climatic drivers due to anthropogenic management. Such hypothesis is reinforced by the fact that periglacial sediment stores are not entirely exhausted in the very upper part of hillslopes. Sedimentation of fine deposits would primarily reflect agrarian landscape structuration (and possibly strategies of soil erosion prevention), as already noticed in other agricultural settings (Follain, 2005; Salvador-Blanes et al., 2006).

\section{Conclusions}

The first results of our geomorphological and pedoanthracological investigations on the Mercurey terroir make it possible to partially decipher the joint evolution of geomorphic processes and landscape over the last 2,800 years. Thereby, two geomorphic phases have been identified within the sedimentary signal: (i) at least from 800 cal. BC, coarse frost heave screes at the base of limestone ledges are progressively reworked and carried out down to the valley bottom through high-energy colluvial processes (e.g., solifluction flows). During this period, connectivity between sedimentary sources and valley bottom is unhindered. Geomorphic processes seem to be favored by a woody vegetation characterized by an opening forest cover for agro-pastoral needs. Species consist mainly of deciduous trees dominated by oak grove taxa and then, subsequently, by riparian taxa; (ii) after $1400 \mathrm{cal}$. AD, the sedimentary signal records a reduction of the geomorphic processes energy. Only small clasts and clayey silts are transported along hillslopes, then filling the valley bottom. At the same time, charcoal assemblages demonstrate a large and almost exclusive presence of vine fragments. This threshold in the sediments grain size coincides with vine sprawling in terms of land use during the Middle Ages. During the medieval period, vineyard landscapes are associated with anthropogenic infrastructures (dry-stone walls, unstructured piles of stones) that reduced sediment connectivity and revealed a strategy of soil resource maintenance.

\section{Acknowledgements}

We thank all the members of the UMR 7264 - CEPAM in Nice, especially Isabelle Théry-Parisot and Claire Delhon who initiated us to charcoal recognition. This study was financially supported by a PhD scholarship from the French Ministry of Higher Education, Research and Innovation. Financial assistance was also provided by the CRGA (Centre de Recherche en Géographie et Aménagement) and the University of Jean Moulin Lyon 3 through the Bourgeon projects AEROSOL (Adaptations à l'érosion des sols, 2018) and ADAGES (Adaptation à la gestion des sols cultivés, 2019).

\section{References}

Amouretti M.-C. (1988) - La viticulture antique : contraintes et choix techniques. Revue des Études Anciennes, tome 90 (1-2), $5-17$.

DOI : $10.3406 /$ rea.1988.4316
Allée P., Lespez L. (2006) - De l'océanique au méditerranéen, la disparité des réponses morphosédimentaires holocènes dans les massifs anciens européens. In Allée P., Lespez L. (Eds.): L'érosion entre société, climat et paléoenvironnement. Table ronde en l'honneur du Professeur René Neboit-Guilhot. Presses Universitaires Blaise Pascal, Clermont-Ferrand, 203-214.

Argant J., Bravard J.-P., Bourguignon J., Béal J. (2011) - Nouvelles données sur les changements paléoenvironnementaux de la plaine alluviale de la Saône depuis le Tardiglaciaire : palynologie, géomorphologie. Quaternaire, 22 (3), 235-260.

DOI : $10.4000 /$ quaternaire. 5984

Bal M., Allée P., Liard M. (2015) - The origins of a Nardus stricta grassland through soil charcoal analyses: Reconstructing the history of a mountain cultural landscape (Mont Lozère, France) since the Neolithic. Quaternary International, 366 (1), 3-14. DOI : 10.1016/j.quaint.2014.11.054

Beaulant R. (2018) - Un terroir pour trois. L'évolution des rapports politiques et sociaux entre le duc de Bourgogne, la mairie de Dijon et les vignerons aux XIVe-XVe siècles. Crescentis : Revue internationale d'histoire de la vigne et du vin, 1, 140-158.

Bégeot C. (2013) - Le comportement pollinique du Noisetier (Corylus avellana), son rôle comme indicateur d'impacts anthropiques? L'exemple d'un transect dans le sud du Jura. Acta Botanica Gallica, 145 (4), 271-279.

DOI : $10.1080 / 12538078.1998 .10516307$

Bertran P. (Dir.) (2004) - Dépôts de pente continentaux : dynamique et faciès. Quaternaire, hors-série (1), $258 \mathrm{p}$.

Bork H.-R., Lang A. (2003) - Quantification of past soil erosion and land use / land cover changes in Germany. In Lang A., Dikau R., Hennrich K. (Eds.): Long term hillslope and fluvial system modelling - Lecture Notes in Earth Sciences. Springer, Berlin Heidelberg, 101, 231-239.

DOI : $10.1007 / 3-540-36606-7 \quad 12$

Brenot J. (2007) - Quantification de la dynamique sédimentaire en contexte anthropisé. L'érosion des versants viticoles de Côte d'Or. Thèse de doctorat, Université de Bourgogne, 318 p.

Campy M. (2017) - La variété des sols viticoles de France, à l'origine de la (bio)diversité des cépages actuels? Bourgogne-FrancheComté Nature, 25, 115-129.

Chaline J. (1976) - Paysages et climats périglaciaires d'après les faunes de rongeurs. Quaternaire, 13 (3), 175-176. DOI : $10.3406 /$ quate. 1976.1295

Ciry R. (1951) - Contribution à l'étude des influences périglaciaires en Bourgogne. Compte-rendu du XXII ${ }^{e}$ Congrès de l'Association bourguignonne des sociétés savantes, Beaune, 3-6.

Ciry R. (1959) - Le rôle du sous-sol gelé quaternaire dans le modelé des plateaux bourguignons. Compte-rendu de l'Académie des Sciences, Paris, 2608-2610.

Clark M.J., Small J.R. (1982) - Slopes and Weathering. Cambridge University Press, Cambridge, $112 \mathrm{p}$.

Cossart E., Fressard M., Chaize B. (in press) - Spatial patterns of vineyard landscape evolution and their impacts on erosion susceptibility: RUSLE simulation applied in Mercurey (Burgundy, France) since the mid-20th century. Catena.

Dambrine E., Dupouey J.L., Laüt L., Humbert L., Thinon M., Beaufils T., Richard H. (2007) - Present forest biodiversity patterns in France related to former Roman agriculture. Ecology, 
88 (6), 1430-1439.

DOI : $10.1890 / 05-1314$

Delhon C. (2005) - Anthropisation et paléoclimats du Tardiglaciaire à l'Holocène en moyenne vallée du Rhône: études pluridisciplinaires des spectres phytolithiques et pédo-anthracologiques de séquences naturelles et de sites archéologiques. Thèse de doctorat, Université de Paris 1, 889 p.

Dion R. (2010) - Histoire de la vigne et du vin en France. Des origines au XIX ${ }^{\mathrm{e}}$ siècle. CNRS Éditions, Paris, 770 p.

Dubouloz, J., Bocquet-Appel J.-P., Moussa R. (2017) Modélisation, simulation et scénarios d'expérimentation. In Manolakakis L., Schlanger N., Coudart A. (Eds.): Archéologie Européenne: Identités \& Migrations - Hommages à Jean-Paul Demoule. Sidestone Press, Leiden, 315-337.

Dutoit T., Thinon M., Talon B., Buisson E., Alard D. (2009) - Sampling soil wood charcoals at a high spatial resolution: a new methodology to investigate the origin of grassland plant communities. Journal of Vegetation Science, 20 (2), 349-358. DOI : $10.1111 /$ j.1654-1103.2009.05403.x

Follain S. (2005) - Effet du réseau bocager sur l'organisation des sols. Redistributions des sols et stockage en carbone organique. Thèse de doctorat, Ecole nationale supérieure d'agronomie de Rennes, 259 p.

Foucher A., Evrard O., Chabert C., Cerdan O., Lefèvre I., Vandromme R., Salvador-Blanes S. (2019) - Erosional response to land abndonment in rural areas of Western Europe during the Anthropocene: A case study in the Massif-Central, France. Agriculture, Ecosystems and Environment, 284, 106582. DOI : 10.1016/j.agee.2019.106582

Foucher A., Salvador-Blanes S., Evrard O., Simonneau A., Chapron E., Courp T., Cerdan O., Lefèvre I., Adriaensen H., Lecompte F., Desmet M. (2014) - Increase in soil erosion after agricultural intensification: Evidence from a lowland basin in France. Anthropocene, 7, 30-41. DOI : $10.1016 /$ j.ancene.2015.02.001

Fressard M., Cossart E. (2019) - A graph theory tool for assessing structural sediment connectivity: Development and application in the Mercurey vineyards (France). Science of The Total Environment, 651, 2566-2584.

DOI : 10.1016/j.scitotenv.2018.10.158

Fressard M., Cossart E., Alami C., Brun G., Potot A., Lejot J., Boulet R., Christol A. (2017) - Casser la connectivité hydrosédimentaire pour gérer la ressource en sol : cas du vignoble de Mercurey (Bourgogne). Géomorphologie: relief, processus, environnement, 23 (4), 309-325.

DOI : $10.4000 /$ geomorphologie. 11865

Garcia J.-P. (2011) - Les sols viticoles de Bourgogne : élaboration naturelle et construction humaine. Revue des œnologues et des techniques vitivinicoles et œnologiques, 141, 62-64.

Garcia J.-P. (2012) - La vigne dans le paysage rural gallo-romain. In: Paysages en mouvement - Les paysages du Mâconnais et du Val de Saône de la Préhistoire à nos jours. Groupement archéologique du Mâconnais, Mâcon, 21-26.

Garcia J.-P. (2014) - La construction des climats viticoles en Bourgogne, la relation du vin au lieu au Moyen Âge. L'Atelier du Centre de recherches historiques, 12.

DOI : $10.4000 /$ acrh.5979
Garcia J.-P., Chevrier S., Dufraisse A., Foucher M., Steinmann R. (2010) - Le vignoble gallo-romain de Gevrey-Chambertin " Au-dessus-de Bergis », Côte-d'Or ( $\mathrm{I}^{\text {er }}-\mathrm{II}^{\mathrm{e}}$ s. ap. J.-C.) : modes de plantation et de conduite de vignes antiques en Bourgogne. Revue archéologique de l'Est, tome 59-2, 505-537.

Garcia J.-P., Chevrier S., Fick N. (2011) - Une vigne gallo-romaine de plaine à Gevrey-Chambertin (Côte-d'Or), $\mathrm{I}^{\mathrm{er}}-\mathrm{II}^{\mathrm{e}}$ s. apr. J.-C. : implications pour le développement des terroirs viticoles de coteaux en Bourgogne. Gallia, 68 (1), 93-110.

Garcia J.-P., Labbé T., Grillon G. (2017a) - Terroirs, climats ... ou le vin et le lieu en Bourgogne. Terroirs et climats, 42-48.

Garcia J.-P., Labbé T., Quiquerez A. (2018) - La préservation et la pérennisation des sols viticoles en Bourgogne du Moyen Âge à nos jours. In Pérard J., Wolikow C. (Dir.): Quelle durabilité en vignes et en cave - Rencontres du Clos Vougeot 2017. 51-65.

Garcia J.-P., Petit C., Quiquerez A., Brenot J., Combaud A., Brigaud B., Petrovic M. (2008) - Données nouvelles de datation des substrats du vignoble en Côte de Beaune et en Côte de Nuits : contribution à l'histoire longue des terroirs viticole. Cahiers d'histoire de la vigne et du vin, 8, 5-11.

Garcia J.-P., Quiquerez A., Delencre F. (2017b) - Des « empreintes géométriques de travaux fossilisés »: les traces de plantations de vignes anciennes (antiques?) à Savigny-Lès-Beaune « La Champagne». Localisation et ré-analyse d'une archive archéologique. Cahiers d'histoire de la vigne et du vin, 14, 3-16.

Gauthier E. (2000) - Mise en évidence pollinique de la culture de la vigne au $1^{\text {er }}$ siècle après J.-C. dans la plaine du Doubs (Neublans, Jura). ArchéoSciences, 24 (1), 63-69.

DOI : $10.3406 /$ arsci.2000.989

Gauthier E., Joly M. (2003) - Vignoble et viticulture dans le Centre-Est de la Gaule au I ${ }^{\text {er }}$ siècle ap. J.-C. In Favory F., Vignot A. (Dir.): Actes du colloque international AGER V, Actualité de la recherche en histoire et archéologie agraires, 19-20 septembre 2000, Besançon. Presses Universitaires de Franche-Comté, Besançon, 191-208.

Goguey R. (1970) - La villa gallo-romaine de Rouvres-en-Plaine : découverte aérienne et fouilles de contrôle, 1966-67. Mémoires de la Commission des antiquités de la Côte-d'Or, tome 26, 219-259.

Haas J., Richoz I., Tinner W., Wick L. (1998) - Synchronous Holocene climatic oscillations recorded on the Swiss Plateau and at timberline in the Alps. The Holocene, 8 (3), 301-309. DOI : $10.1191 / 095968398675491173$

Haasé P. (1977) - Bibliographie analytique et critique des ouvrages traitant des vestiges lithiques d'origine agricole en Bourgogne. L'architecture rurale en pierre sèche - Revue de l'architecture populaire et anonyme, tome 1 .

Harfouche R. (2017) - Archéologie et histoire des maçonneries à pierres sèches ». In Cagin L. (Dir.): Pierre sèche - Théorie et pratique d'un système traditionnel de construction. Éditions Eyrolles, Paris, 8-31.

Huygen M. (1988) - Villas gallo-romaines au lieu-dit « La rente de Mars » à Brognon (Côte-d'Or). Bulletin de liaison de la Direction des antiquités historiques de Bourgogne, 4, 8.

Jorda M., Provansal M. (1990) - Terrasses de culture et bilan érosif en région méditerranéenne. Le bassin-versant du Vallat de Monsieur (Basse-Provence). Méditerranée, tome 71 (3-4), 55-61. DOI : $10.3406 /$ medit.1990.2686 
Jouffroy-Bapicot I. (2010) - Évolution de la végétation du massif du Morvan (Bourgogne - France) depuis la dernière glaciation à partir de l'analyse pollinique. Variations climatiques et impact des activités anthropiques. Thèse de doctorat, Université de Franche-Comté, 373 p.

Labbé T., Garcia J.-P. (2019) - Amendement et renouvellement des sols dans la viticulture bourguignonne aux $\mathrm{XIV}^{\mathrm{e}}$ et $\mathrm{XV}^{\mathrm{e}}$ siècles. In Conesa M., Poirier N. (Dir.): Fumiers! Ordures! Gestion et usage des déchets dans les campagnes de l'Occident médiéval et moderne. Presses Universitaires du Mirail, Toulouse, 69-85.

de Lafontaine G., Asselin H. (2011) - Soil charcoal stability over the Holocene across boreal northeastern North America. Quaternary Research, 76 (2), 196-200.

DOI : $10.1016 /$ j.yqres.2011.06.006

Laine A., Gauthier E., Garcia J.-P., Petit C., Cruz F., Richard H. (2010) - A three-thousand-year history of vegetation and human impact in Burgundy (France) reconstructed from pollen and nonpollen palynomophs analysis. Comptes Rendus Biologies, 333 (11-12), 850-857.

DOI : $10.1016 /$ j.crvi.2010.08.006

Larsen A., Robin V., Heckmann T., Fülling A., Larsen J., Bork H.R. (2016) - The influence of historic land-use changes on hillslope erosion and sediment redistribution. The Holocene, 26 (8), 1-14. DOI : $10.1177 / 0959683616638420$

Lasanta, T., Arnáez J., Pascual N., Ruiz-Flaño P., Errea M.P., Lana-Renault N. (2017) - Space-time process and drivers of land abandonment in Europe. Catena, 149, 810-23.

DOI : 10.1016/j.catena.2016.02.024

van der Leeuw S.E. (2005) - Climate, hydrology, land use, and environmental degradation in the lower Rhone Valley during the Roman period. Comptes Rendus Geoscience, 337 (1), 9-27. DOI : $10.1016 /$ j.crte.2004.10.018

Leneuf N., Puisségur J.-J. (1976) - Minéraux argileux et conditions paléoécologiques dans les dépôts quaternaires de versants en Bourgogne. Quaternaire, 13 (3), 145-156.

DOI : $10.3406 /$ quate.1976.1289

Lynch J.A, Clark J.S., Stocks B.J. (2004) - Charcoal production, dispersal, and deposition from the Fort Providence experimental fire: interpreting fire regimes from charcoal records in boreal forest. Canadian Journal of Forest Research, 34 (8), 1642-1656.

DOI : $10.1139 / \mathrm{x} 04-071$

Magny M. (2004) - Holocene climate variability as reflected by mid-European lake-level fluctuations and its probable impact on prehistoric human settlements. Quaternary International, 113 (1), 65-79.

\section{DOI : $10.1016 / \mathrm{S} 1040-6182(03) 00080-6$}

Magny M. (2013) - Orbital, ice-sheet, and possible solar forcing of Holocene lake-level fluctuations in west-central Europe: A comment on Bleicher. The Holocene, 23 (8), 1202-1212.

DOI : $10.1177 / 0959683613483627$

Magny M., Haas J. (2004) - A major widespread climatic change around $5300 \mathrm{cal}$. yr BP at the time of the Alpine Iceman. Journal of Quaternary Science, 19 (5), 423-430.

DOI : 10.1002 /iqs. 850

Magny M., Mouthon J., Ruffaldi P. (1995) - Late holocene level fluctuations of the lake Ilay in Jura, France: sediment and mollusc evidence and climatic implications. Journal of Paleolimnology, 13

\section{(3), 219-229.}

\section{DOI : $10.1007 / \mathrm{BF} 00682766$}

Mangerud J., Andersen S., Berglund B., Donner J. (1974) Quaternary stratigraphy of Norden, a proposal for terminology and classification. Boreas, 3 (3), 109-126.

DOI : 10.1111/j.1502-3885.1974.tb00669.x

Mann M.E., Zhang Z., Hughes M.K., Bradley R.S., Miller S.K., Rutherford S., Ni F. (2008) - Proxy-based reconstructions of hemispheric and global surface temperature variations over the past two millennia. Proceedings of the National Academy of Sciences, 105 (36), 13252-13257. DOI : $10.1073 /$ pnas.0805721105

Mériaux S., Chretien J., Vermi P., Leneuf N. (1981) - La Côte viticole, ses sols et ses crus. Bulletin Scientifique de Bourgogne, 34, 17-40.

Miall A.D. (1985) - Architectural-element analysis: A new method of facies analysis applied to fluvial deposits. Earth-Science Reviews, 22 (4), 261-308.

DOI : $10.1016 / 0012-8252(85) 90001-7$

Peters M., Higuera P. (2007) - Quantifying the source area of macroscopic charcoal with a particle dispersal model. Quaternary Research, 67 (2), 304-310.

DOI : $10.1016 /$ j.yqres.2006.10.004

Planson E. (1970) - L'habitat rural gallo-romain et la stèle du « dieu aux oiseaux » de Moux (commune de Corgoloin, Côte-d'Or). Rapport avec le problème de l'origine du vignoble bourguignon. Mémoires de la Commission des antiquités de la Côte-d'Or, tome 26, 211-217.

Provansal M., Leveau P. (2006) - Morphogenèse, anthropisation et changements climatiques: état du champ scientifique. In Allée P., Lespez L. (Eds.): L'érosion entre société, climat et paléoenvironnement. Table ronde en l'honneur du Professeur René Neboit-Guilhot. Presses Universitaires Blaise Pascal, Clermont-Ferrand, 191-202.

Quiquerez A., Garcia J.-P., Follain S. (2018) - Évolution et transformation des sols viticoles en lien avec l'évolution et la dynamique des paysages et parcellaires viticoles. Revue des œnologues et des techniques vitivinicoles et œnologiques, 169, 29-31.

Rat P. (1953) - Observations sur la solifluxion dans les dépôts de pente du Châtillonnais. Compte-rendu du XIV ${ }^{e}$ Congrès de l'Association bourguignonne des sociétés savantes, Dijon, $4 \mathrm{p}$.

Reimer P., Bard E., Bayliss A., Beck J.W., Blackwell P., Ramsey C., Buck C., Cheng H., Edwards R., Friedrich M., Grootes P., Guilderson T., Haflidason H., Hajdas I., Christine H., Heaton T., Hogg A., Hughen K., Kaiser K., Staff R., Turney C., van der Plicht J. (2013) - IntCal13 and Marinel3 radiocarbon age calibration curves 0-50,000 years cal BP. Radiocarbon, 55 (4), 1869-1887.

DOI : $10.2458 /$ azu_js rc. 55.16947

Richard H. (1999) - La palynologie. In Bourquin-Mignot C., Brochier J.-E., Chabal L., Crozat S., Fabre L., Guibal F., Marinval P., Richard H., Terral J.-F., Théry-Parisot I.: La botanique. Éditions Errance, Paris, 9-42.

Robin V., Talon B., Nelle O. (2013) - Pedoanthracological contribution to forest naturalness assessment. Quaternary International, 289 (1), 5-15. 


\section{DOI : 10.1016/i.quaint.2012.02.023}

Salvador-Blanes S., Cornu S., Couturier A., King D., Macaire J.-J. (2006) - Morphological and geochemical properties of soil accumulated in hedge-induced terraces in the Massif Central, France. Soil and Tillage Research, 85 (1), 62-77. DOI : $10.1016 /$ j.still.2004.12.008

Schweingruber F.H. (1990) - Anatomy of European wood: an atlas for the identification of European trees, shrubs and dwarf shrubs. Paul Haupt, Bern, 800 p.

Tarolli P., Preti F., Romano N. (2014) - Terraced landscapes: from an old best practice to a potential hazard for soil degradation due to land abandonment. Anthropocene, 6, 10-25. DOI : 10.1016/j.ancene.2014.03.002

Touflan P., Talon B., Walsh K. (2010) - Soil charcoal analysis: a reliable tool for spatially precise studies of past forest dynamics: a case study in the French southern Alps. Holocene, 20 (1), 45-52. DOI : $10.1177 / 0959683609348900$

Vernet J.-L., Ogereau P., Figueiral I., Machado Yanes C., Uzquiano P. (2001) - Guide d'identification des charbons de bois préhistoriques et récents. Sud-ouest de l'Europe: France, Péninsule ibérique et Îles Canaries. CNRS Éditions, Paris, 395 p.

Vernou C. (2009) - À propos de viticulture antique en Côte-d'Or. In Provost M.: Carte archéologique de la Gaule 21/1 : La Côte-d'Or (Alésia). Éditions de la Maison des sciences de l'homme, Paris, 265-266.

Zech-Matterne V., Bouby L., Coubray S., Boulen M., Lemaître S. (2011) - Viticulture et viniculture dans le nord du bassin parisien d'après les données archéobotaniques. Gallia, 68, (1), 257-262.

\section{Version abrégée en français}

Sur le territoire français, de nombreux travaux ont étudié à l'échelle régionale l'évolution du couvert végétal, en lien avec le climat et les grandes phases d'anthropisation du paysage au cours de l'Holocène (Allée et Lespez, 2006 ; Provansal et Leveau, 2006). En complément, des études à une échelle plus locale sont nécessaires pour comprendre les conséquences des activités humaines (e.g., pratiques agricoles) sur les processus géomorphologiques (Larsen et al., 2016). Cela permet ainsi de discuter la synchronie entre la mise en culture des paysages et l'augmentation du signal érosif.

Nous nous intéressons dans cet article à la Côte viticole de Bourgogne (Centre-Est de la France) où les études historiques ont montré une longue tradition dans la gestion de la ressource en sol: des aménagements agricoles telles que des terrasses de culture et des murs de pierres sont construites depuis le début du Moyen-Âge (Garcia et al., 2017a), et certaines dateraient même de périodes antérieures (Hasée, 1977 ; Harfouche, 2017). Au sein du vignoble bourguignon, nos recherches portent plus précisément sur le site de Mercurey. Le choix de cette fenêtre d'étude a été motivé par trois raisons : (i) depuis le milieu du XXe siècle, les aménagements agricoles et l'évolution des modes d'occupation du sol ont directement influencé le niveaux des taux d'érosion (Fressard et al., 2017 ; Fressard et Cossart, 2019), révélant des stratégies de gestion de la ressource en sol (Cossart et al., sous presse) ; (ii) un état des connaissances paléoenvironnementales assez lacunaire sur la Côte Chalonnaise en général et le terroir de Mercurey en particulier, l'évolution de leur couvert végétal étant interprétée par analogie avec les données issues de zones périphériques, notamment le nord de la Côte de Bourgogne, la vallée de la Saône, le massif du Morvan et le piémont du Jura; (iii) le site de Mercurey présente un contexte topographique favorable au stockage d'archives sédimentaires. Il est caractérisé par un bassin versant bien circonscrit, contrairement à la plupart des autres terroirs bourguignons qui sont principalement des vignobles de côte en prise directe avec la plaine de la Saône.

Une analyse géomorphologique de ce bassin versant est menée. Elle se fonde sur la lecture de faciès sédimentaires menée de façon aussi exhaustive que possible le long des versants et dans le fond de vallée. Une description stratigraphique, couplée à des datations par le radiocarbone, permet de reconstituer l'histoire de la sédimentation et des principales phases détritiques. L'interprétation du signal sédimentaire reconstituée est réalisée à l'aune de données pédoanthracologiques acquises in situ. La présence de charbons dans les niveaux historiques sert en effet de marqueur des activités anthropiques, et notamment de l'activité viticole puisque les produits de la taille de la vigne sont brûlés depuis l'époque gallo-romaine (Amouretti, 1988). Le croisement de ces données sédimentaires et paléoenvironnementales permet de mettre en évidence les interactions entre les modes d'occupation du sol, les pratiques agricoles et les processus géomorphologiques au cours des 2800 dernières années.

Au moins à partir de $800 \mathrm{cal}$. BC, une sédimentation grossière se développe dans le fond de vallée. Elle se compose de clastes anguleux pluricentimétriques insérés dans une matrice limono-argileuse et charriés par des processus géomorphologiques de haute intensité (e.g., coulées de solifluxion). Ces dynamiques colluviales remanient les matériaux issus du démantèlement cryoclastique des corniches calcaires, opéré au cours du Pléistocène, et stockés jusqu'alors sur les hauts de versant. Le signal pédoanthracologique, quant à lui, enregistre la présence d'une végétation diversifiée et rattachée à des formations forestières de versant (Quercus sp., Fagus sylvatica, Corylus avellana) et de fond de vallée (Salix sp., Populus sp.). Les résidus carbonisés de ces essences végétales peuvent être interprétés comme une phase d'anthropisation caractérisée par des pratiques de déforestation en lien avec des besoins agropastoraux. Les rares fragments de vigne (Vitis sp.) identifiés lors de cette première phase ne peuvent être discriminés entre la forme sauvage de la vigne qui pousse naturellement dans la ripisylve, en compagnie du saule/peuplier, et sa forme cultivée qui est apparue en Bourgogne aux alentours de $150 \mathrm{cal}$. AD (Garcia et al., 2010).

Après 1400 cal. AD, il s'opère une rupture à la fois dans la granulométrie des sédiments accumulés dans le fond de vallée et dans les assemblages pédoanthracologiques. Une sédimentation fine se met en place, interprétée comme le résultat d'une stratégie de gestion de la ressource en sol. Au cours du Moyen-Âge, des murs de pierres sèches et des tas de pierres d'épierrement (" meurgers ") sont érigés suite à la diffusion de la viticulture dans le paysage (Garcia, 2014). Ces aménagements agricoles perméables jouent le rôle de tamis en piégeant les sédiments grossiers sur les versants tout en laissant passer les eaux de ruissellement chargées en sédiments fins. L'emprise spatiale grandissante de la vigne et l'attention particulière des sociétés pour cette plante semblent se refléter dans les données pédoanthracologiques. Elles sont quasi-monospécifiques et révèlent une concentration importante en charbons de vigne. 